\title{
Wie A zegt, zegt ook B?
}

Citation for published version (APA):

Allen, J., \& Belfi, B. (2018). Wie A zegt, zegt ook B? Opleidingsoordelen van HBO-studenten en afgestudeerden nader vergeleken. ROA. ROA Reports No. 002 https://doi.org/10.26481/umarep.2018002

Document status and date:

Published: 01/01/2018

DOI:

10.26481/umarep.2018002

Document Version:

Publisher's PDF, also known as Version of record

\section{Please check the document version of this publication:}

- A submitted manuscript is the version of the article upon submission and before peer-review. There can be important differences between the submitted version and the official published version of record.

People interested in the research are advised to contact the author for the final version of the publication, or visit the DOI to the publisher's website.

- The final author version and the galley proof are versions of the publication after peer review.

- The final published version features the final layout of the paper including the volume, issue and page numbers.

Link to publication

\footnotetext{
General rights rights.

- You may freely distribute the URL identifying the publication in the public portal. please follow below link for the End User Agreement:

www.umlib.nl/taverne-license

Take down policy

If you believe that this document breaches copyright please contact us at:

repository@maastrichtuniversity.nl

providing details and we will investigate your claim.
}

Copyright and moral rights for the publications made accessible in the public portal are retained by the authors and/or other copyright owners and it is a condition of accessing publications that users recognise and abide by the legal requirements associated with these

- Users may download and print one copy of any publication from the public portal for the purpose of private study or research.

- You may not further distribute the material or use it for any profit-making activity or commercial gain

If the publication is distributed under the terms of Article $25 \mathrm{fa}$ of the Dutch Copyright Act, indicated by the "Taverne" license above, 
Research Centre for Education and the Labour Market | ROA

\section{Wie A zegt, zegt ook B?}

\section{Opleidingsoordelen van hbo-studenten en afgestudeerden nader vergeleken}

\section{ROA Rapport}

ROA-R-2018/2

Researchcentrum voor Onderwijs en Arbeidsmarkt | ROA Research Centre for Education and the Labour Market / ROA 


\section{WIE A ZEGT, ZEGT OOK B?}

\section{OPLEIDINGSOORDELEN VAN HBO-STUDENTEN EN AFGESTUDEERDEN NADER VERGELEKEN}

Jim Allen

Barbara Belfi

ROA-R-2018/2 


\section{Colofon}

(c) Researchcentrum voor Onderwijs en Arbeidsmarkt (ROA). Niets uit deze uitgave mag op enige manier worden verveelvoudigd zonder voorafgaande schriftelijke toestemming van de directeur van het ROA.

\section{Researchcentrum voor Onderwijs en Arbeidsmarkt}

School of Business and Economics

Maastricht University

email: secretary-roa-sbe@maastrichtuniversity.nl

website: www.roa.nl

\section{Redactie en productie}

Researchcentrum voor onderwijs en arbeidsmarkt (ROA)

\section{Vormgeving}

ROA secretariaat, Maastricht

ISBN: 978-90-5321-571-5

oktober 2018 


\section{INHOUD}

\section{Pagina}

Belangrijkste bevindingen en conclusies

01 Inleiding

02 Hoe consistent zijn studenten en afgestudeerden in de beoordeling van hun hbo-opleiding

03 Nadere analyse van verschillen tussen Hbo-Monitor en NSE 17

04 Wat voegt de Hbo-Monitor toe?

05 Discussie en conclusies

Bijlage 1 Robuuste schattingen van gemiddelde oordelen 


\section{Dankwoord}

In dit rapport wordt naast gegevens uit de HBO-Monitor gebruik gemaakt van data van de Nationale Studenten Enquête (NSE). Wij danken Lex Sijtsma en Nisan Mol van Studiekeuze123 en Puck Wijker en Celine Simons van GfK voor het leveren van het definitieve NSE benchmarkbestand van 2013-2017, met bijbehorende documentatie. De analyses en conclusies in dit rapport nemen wij geheel voor onze eigen rekening. 


\section{BELANGRIJKSTE BEVINDINGEN EN CONCLUSIES}

In dit rapport worden de resultaten beschreven van een gemeenschappelijke analyse van gegevens uit de HBO-Monitor en NSE. Hiervoor zijn de uitkomsten van beide onderzoeken m.b.t. afstudeerjaar 2015 gekoppeld op het geaggregeerde niveau van opleiding (croho) maal instelling (brin) maal vestiging (gemeente). De belangrijkste bevindingen en conclusies zijn als volgt:

1. Er is sprake van een zeer sterke relatie tussen $\mathrm{HBO}-$ Monitor oordelen en NSE-oordelen van studenten die in het laatste jaar van hun hbo-opleiding zitten. Deze sterke consistentie op basis van twee onderzoeken die volledig los van elkaar worden uitgevoerd kan worden gezien als een krachtige validering van beide onderzoeken.

2. Deze relatie is wel zwakker bij oordelen waarvoor een afwijkende antwoordschaal is gebruikt in de HBO-Monitor dan in de NSE. Hieruit blijkt dat vergelijkingen gebaseerd op verschillende antwoordschalen onbetrouwbaar kunnen zijn. De resultaten lijken daarentegen niet gevoelig te zijn voor variaties in de vraagformulering.

3. Voor zover als een vergelijking in de tijd mogelijk is, lijken trends in NSE oordelen in grote lijnen consistent te zijn met trends in HBO-Monitor oordelen. Hierbij dient echter opgemerkt te worden dat de overlap in uitstroomjaren tussen beide onderzoeken erg beperkt is. Het verdient dus aanbeveling om deze vergelijking over een paar jaar te herhalen.

4. Gemiddeld is sprake van weinig verschil tussen NSE en HBO-Monitor oordelen. Het enige verschil is dat afgestudeerden gemiddeld genomen iets positiever dan studenten zijn over de kwaliteiten van hun docenten, en iets negatiever over de voorbereiding op de arbeidsmarkt.

5. Wanneer we kijken naar oordelen van specifieke opleidingen binnen specifieke instellingen, is er echter vaak sprake van forse verschuivingen. In sommige gevallen zijn afgestudeerden dan positiever dan studenten, in andere gevallen juist negatiever.

6. In een aantal gevallen blijken de verschuivingen in oordelen sterk samen te hangen met de ervaringen na het verlaten van de opleiding. Zo blijkt het gemiddelde arbeidsmarktsucces van specifieke opleidingen binnen specifieke instellingen positief samen te hangen met een verschuiving in het oordeel over de voorbereiding op 
de arbeidsmarkt en de bereidheid om de opleiding aan anderen aan te raden. Het aandeel doorstromers naar vervolgonderwijs hangt daarnaast negatief samen met verschuivingen in oordelen over docenten.

7. Er zijn indicaties dat verschuivingen deels worden gedreven door individuele ervaringen op de arbeidsmarkt. Een veel sterker effect lijkt echter te kunnen worden toegeschreven aan de opleiding/instelling.

8. Bij een viertal oordelen - voorbereiding op beroepsloopbaan, de bereidheid de opleiding bij familie en vrienden aan te raden, de studie in het algemeen en de inhoudelijke samenhang - blijkt de HBO-Monitor een bijzonder sterke toegevoegde waarde te hebben ten opzichte van de NSE. Dit zijn aspecten waarbij het deel van de HBO-Monitor-oordelen dat niet reeds door NSE-oordelen kon worden verklaard, sterk samenhangt met arbeidsmarktsucces en doorstroom naar vervolgonderwijs. 


\section{1 \\ INLEIDING}

Het belangrijkste doel van de HBO-Monitor is het in kaart brengen van de transitie van hbo-afgestudeerden naar de arbeidsmarkt, en in sommige gevallen naar vervolgonderwijs. Om deze reden bevat de jaarlijkse HBO-Monitor vragenlijst een reeks vragen over het zoeken naar werk in de periode na afstuderen, de bereikte maatschappelijke positie circa een jaar na afstuderen, voor doorstudeerders het type vervolgopleiding, en voor werkenden de belangrijkste kenmerken van de huidige baan. Hiernaast worden echter ook een aantal oordeelsvragen gesteld over aspecten van de gevolgde hbo-opleiding zoals de tevredenheid over de voorlichting over en voorbereiding op de beroepsloopbaan, de inhoud van de opleiding, de docenten, en de studie in het algemeen. Ook in de Nationale Studenten Enquête (NSE) worden studenten jaarlijks gevraagd naar hun oordeel over hun hbo of wo-opleiding.

De rationale om naast transitiegerelateerde vragen, tevens een aantal oordeelsvragen in de $\mathrm{HBO}-M o n i t o r$ op te nemen is tweeledig. Enerzijds dienen oordelen van afgestudeerden als context bij het interpreteren van de uitkomsten van het transitieproces. Wanneer afgestudeerden van een bepaalde hbo-opleiding opvallend vaak een relatief goede of slechte overgang naar de arbeidsmarkt en/of het vervolgonderwijs beleven, kan het uit oogpunt van kwaliteitsbewaking en onderwijsverbetering nuttig zijn om te weten of dit gepaard gaat met corresponderende positieve of negatieve oordelen over aspecten van de opleiding. Anderzijds kunnen oordelen van afgestudeerden andere informatie bevatten dan die van studenten, omdat ze door hun ervaring op de arbeidsmarkt of in het vervolgonderwijs de opleiding in een ander daglicht komen te zien.

Tegen deze achtergrond is opvallend dat er weinig of geen systematische kennis is van hoe de oordelen van afgestudeerden zich verhouden tot de oordelen van de studentenpopulatie waartoe ze zich tot voor kort behoorden. Deze kennislacune vormt een onnodige beperking van de gebruikswaarde van zowel de NSE als de HBO-Monitor, omdat de gebruikers van deze instrumenten geen inzicht hebben in (a) de mate waarin de uitkomsten van beide onderzoeken in dezelfde richting wijzen, en (b) hoe ze eventuele verschillen tussen oordelen van studenten en afgestudeerden moeten interpreteren. Met het huidige onderzoek wordt een eerste stap gezet in de richting van het opheffen van deze kennislacune. In dit rapport worden de resultaten beschreven van 
een gemeenschappelijke analyse van gegevens uit de HBO-Monitor en NSE. Hiervoor zijn de uitkomsten van beide onderzoeken m.b.t. afstudeerjaar 2015 gekoppeld op het geaggregeerde niveau van opleiding (croho) maal instelling (brin) maal vestiging (gemeente). De gekoppelde data hebben betrekking op hbo voltijd bachelors uit studiejaar 2013-14, die in 2014 -gedurende hun laatste studiejaar-in het kader van de NSE zijn bevraagd over hun opleidingsoordeel, en in 2015 soortgelijke oordeelsvragen opnieuw hebben beantwoord in het kader van de HBO-Monitor toen ze ruim één jaar waren afgestudeerd.

De analyses richten zich op een aantal oordeelsvragen waarvan in beide onderzoeken een min of meer equivalente vraagstelling is toegepast (zie tabel 1.1 voor een overzicht). Er wordt gekeken in hoeverre deze oordelen met elkaar samenhangen, en in hoeverre de oordelen in beide onderzoeken met arbeidsmarktsucces samenhangen. Er wordt tevens onderzocht in hoeverre arbeidsmarktsucces samenhangt met een verschuiving in het gemiddelde oordeel tussen NSE en HBO-Monitor, m.a.w. in hoeverre afgestudeerden hun oordelen aanpassen aan de feitelijke situatie na afstuderen.

Voor veel van de eenheden geldt dat we voor de betreffende periode over slechts weinig waarnemingen beschikken, waardoor er sprake is van een grote meetfout in resultaten. Om het storende effect hiervan te reduceren maken we gebruik gemaakt van multiniveau analysemodellen. Voor een uitgebreide uitleg over deze analysemethode wordt verwezen naar bijlage 1. 


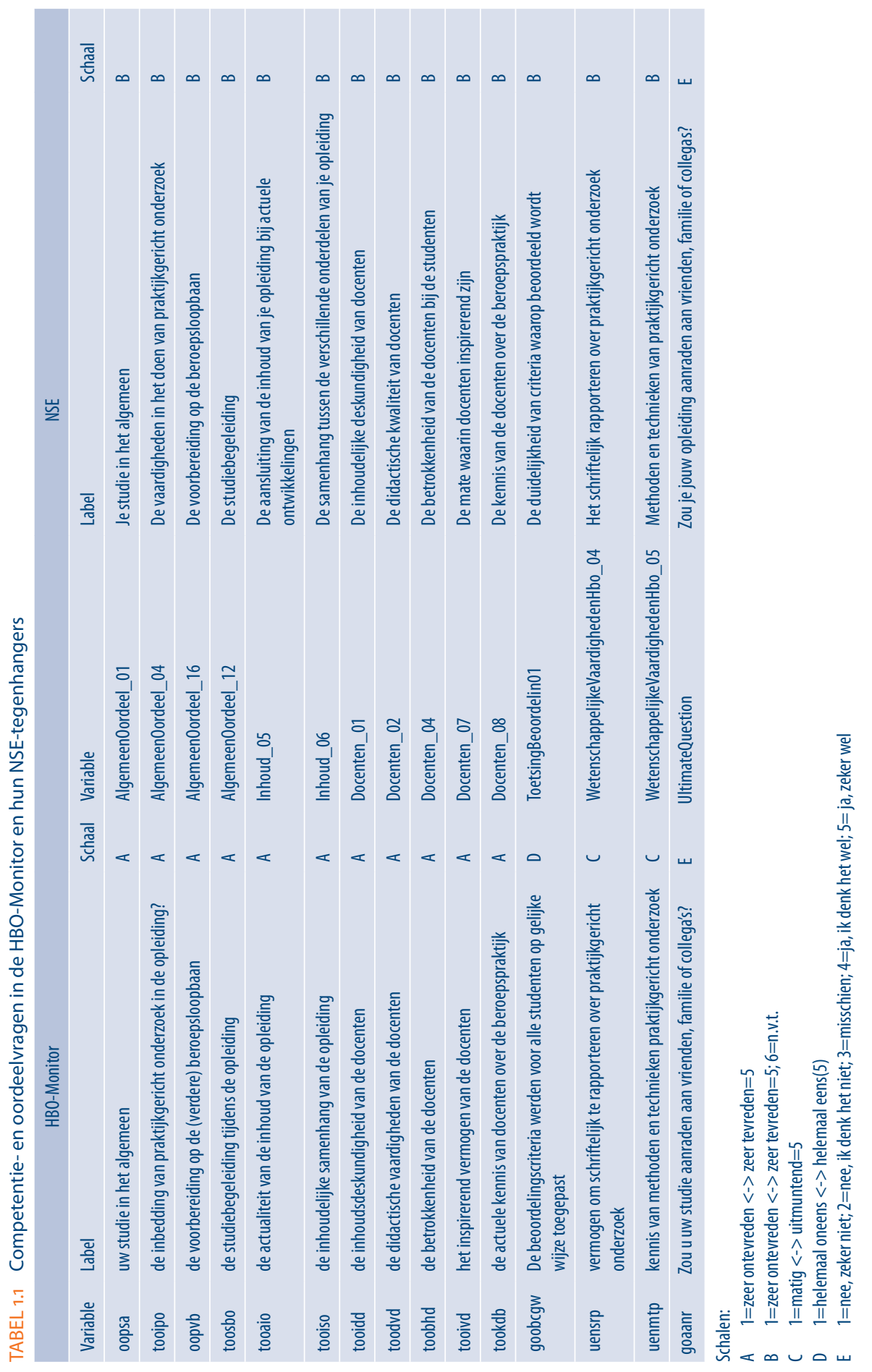





\section{HOE CONSISTENT ZIJN STUDENTEN EN AFGESTUDEERDEN IN DE BEOORDELING VAN HUN HBO-OPLEIDING?}

\section{Hoe zien de opleidingsoordelen van afgestudeerden eruit?}

In deze paragraaf geven we allereerst een overzicht van opleidingsoordelen van afgestudeerden die ruim een jaar na afstuderen terugkijken op hun hbo-opleiding. Vervolgens vergelijken we deze met oordelen van studenten in het laatste studiejaar.

FIGUUR 2.1 Oordelen van HBO-afgestudeerden op 15 aspecten van de gevolgde opleiding

\author{
Studie aanraden \\ Inhoudsdeskundigheid docenten \\ Betrokkenheid van docenten \\ Actualiteit inhoud van de opleiding \\ Actuele kennis docenten over beroepspraktijk \\ Studie in het algemeen \\ Inhoudelijke samenhang van de opleiding \\ Schriftelijk rapporteren praktijkgericht onderzoek \\ Didactische vaardigheden docenten \\ Inspirerend vermogen docenten \\ Inbedding praktijkgericht onderzoek in opleiding \\ Methoden en technieken praktijkgericht onderzoek \\ Beoordelingscriteria gelijk \\ Studiebegeleiding tijdens opleiding \\ Voorbereiding op beroepsloopbaan
}

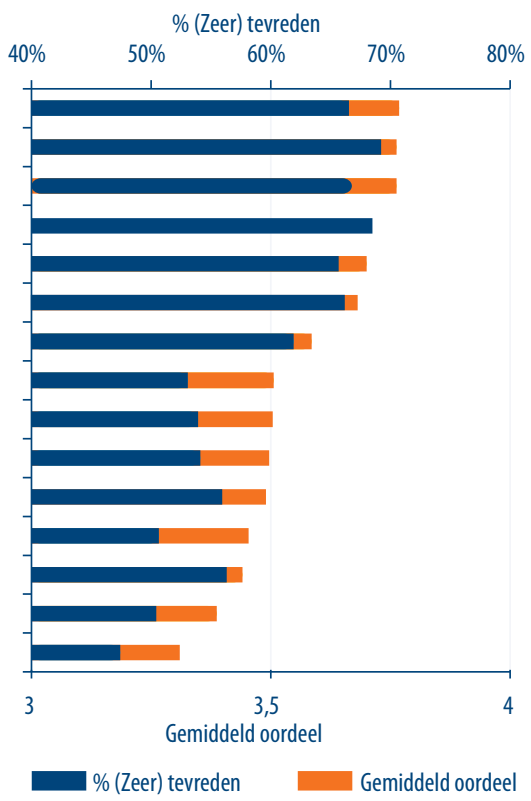

Figuur 2.1 toont het gemiddelde oordeel van afgestudeerden ten aanzien van vijftien opleidingsaspecten op een 5-punt schaal, en het aandeel afgestudeerden dat hierover 
"tevreden" of "zeer tevreden" was (antwoordcategorie 4 en 5). ' Hoewel er wat kleine verschillen te zien zijn in de rangordening van de oordelen (gemiddelde oordeel versus percentage (zeer) tevreden), zijn de afwijkingen zijn niet groot. Uit nadere analyses (beschikbaar op aanvraag), blijkt dat het voor de meeste resultaten niet veel uitmaakt welke maat we kiezen. Om onnodige herhaling te voorkomen werken we daarom verder uitsluitend met gemiddelden, aangezien deze gebruik maken van de volledige antwoorden van alle deelnemende afgestudeerden en studenten, en daarmee een stabieler beeld geven van de overeenkomsten en verschillen tussen de twee metingen.

Omdat het hier om een vergelijking tussen HBO-Monitor en NSE gaat, worden in de rest van het rapport uitsluitend cijfers gepresenteerd van eenheden die in beide onderzoeken zijn vertegenwoordigd in het betreffende jaar. Hiermee wordt voorkomen dat eventuele verschillen in samenstelling tussen de HBO-Monitor en NSE in termen van deelnemende opleidingen en instellingen de vergelijking verstoren. Uit figuur 2.2 blijkt dat dit voor de HBO-Monitor oordelen in hoofdlijnen niet veel uitmaakt.

FIGUUR 2.2 Oordelen van alle HBO-afgestudeerden vergeleken met afgestudeerden van opleidingen en instellingen die ook aan NSE hebben deelgenomen

Studie aanraden

Inhoudsdeskundigheid docenten

Betrokkenheid van docenten

Actualiteit inhoud van de opleiding

Actuele kennis docenten over beroepspraktijk

Studie in het algemeen

Inhoudelijke samenhang van de opleiding

Schriftelijk rapporteren praktijkgericht onderzoek

Didactische vaardigheden docenten

Inspirerend vermogen docenten

Inbedding praktijkgericht onderzoek in opleiding

Methoden en technieken praktijkgericht onderzoek

Beoordelingscriteria gelijk

Studiebegeleiding tijdens opleiding

Voorbereiding op beroepsloopbaan

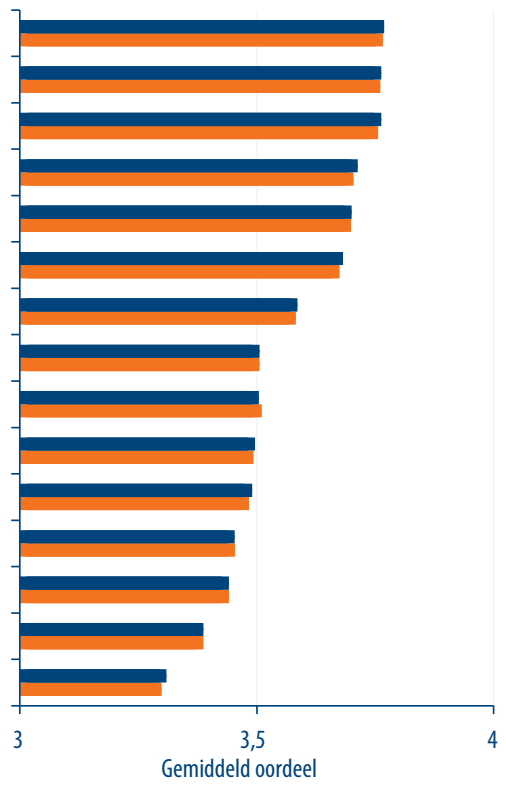

Alle eenheden
Eenheden die ook aan

NSE hebben deelgenomen

1 Voor een klein aantal aspecten gaat het niet letterlijk om tevredenheid, maar wordt een andere antwoordschaal gebruikt (zie tabel 1.1). 


\section{Hoe vergelijkbaar zijn oordelen van studenten en afgestudeerden?}

In figuur 2.3 zetten we de gemiddelde oordelen van afgestudeerden af tegen de oordelen van studenten. Zoals hierboven reeds is opgemerkt wordt in dit rapport vooral naar oordelen van studenten in het laatste studiejaar gekeken, omdat dit voor het grootste deel ook de mensen zijn die ruim één jaar later hebben deelgenomen aan de HBO-Monitor. Omdat de NSE jaarlijks wordt uitgevoerd onder alle jaargangen van het hbo en wo, hadden we in theorie gebruik kunnen maken van het gehele NSE-bestand bestaande uit eerste $\mathrm{t} / \mathrm{m}$ vierdejaars studenten. Door het groter aantal observaties zouden we daardoor tot betrouwbaardere schattingen kunnen komen. Echter, uitgaande van de assumptie dat de meeste studenten die in het laatste jaar van de studie deel hebben genomen aan de NSE, daadwerkelijk in datzelfde jaar de studie hebben afgerond, geeft dit een meer valide benadering van de populatie van de HBO-Monitor. Om aan te tonen dat deze selectie belangrijk is, worden in figuur 2.3 ook de gemiddelden van alle NSE bachelor-studenten getoond, dus ook studenten in het eerste, tweede en derde leerjaar. De diagonaallijn in deze grafiek geeft aan waar de oordelen van afgestudeerden zouden liggen wanneer de studentenoordelen en afgestudeerdenoordelen aan elkaar gelijk zouden zijn.

\section{FIGUUR 2.3 Oordelen van alle HBO-afgestudeerden afgezet tegen oordelen van studenten}

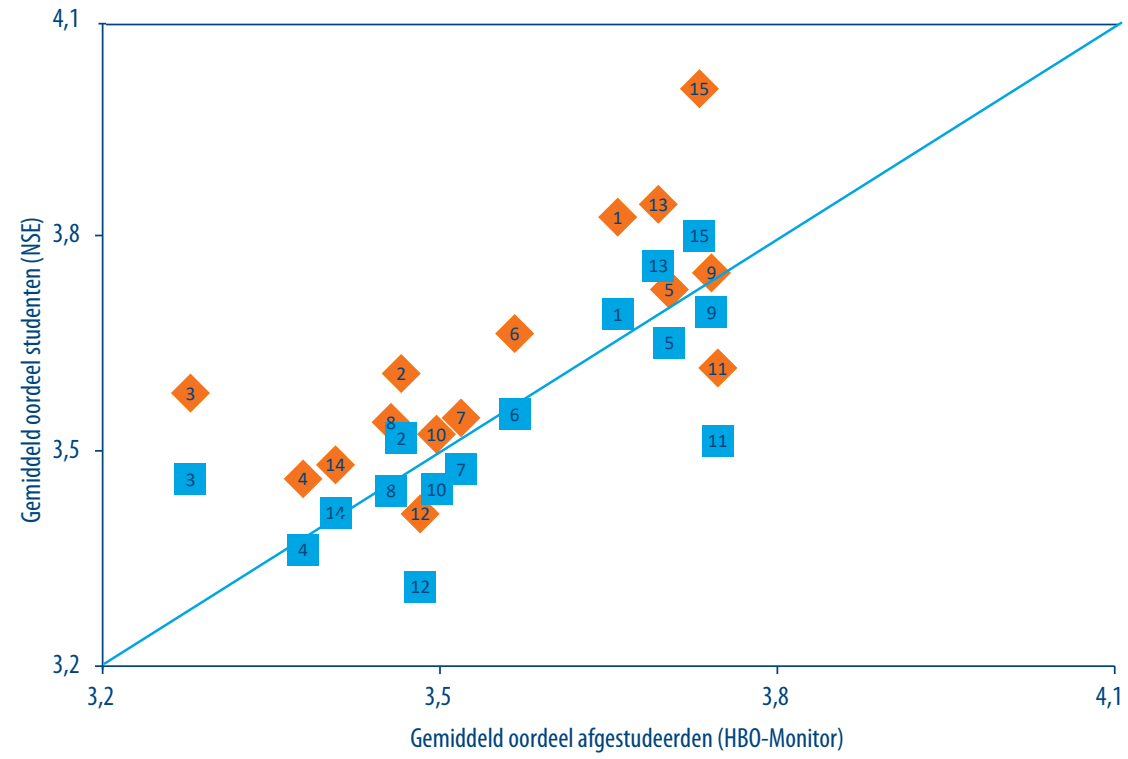

\section{Legenda:}

1 studie in het algemeen

2 inbedding praktijkgericht onderzoek in opleiding 10

3 voorbereiding op beroepsloopbaan

4 studiebegeleiding tijdens opleiding

5 actualiteit inhoud van de opleiding

6 inhoudelijke samenhang van de opleiding

7 schriftelijk rapporteren praktijkgericht onderzoek

8 methoden en technieken praktijkgericht onderzoek
NSE alle bachelors

9 inhoudsdeskundigheid docenten

10 didactische vaardigheden docenten

11 betrokkenheid van docenten

12 inspirerend vermogen docenten

13 actuele kennis docenten over beroepspraktijk

14 beoordelingscriteria gelijk

studie aanraden 
Het is opvallend dat de gecombineerde oordelen van studenten in alle leerjaren van de bacheloropleiding (de oranje ruitjes) meestal boven de diagonaallijn liggen, en ook boven de oordelen van studenten van uitsluitend het laatste leerjaar van de bacheloropleiding (de blauwe vierkantjes). Hieruit blijkt dat studenten door de bank genomen kritischer worden over hun opleiding naarmate ze langer met hun studie bezig zijn. Uit het feit dat de blauwe vierkantjes doorgaans dichter bij de diagonaallijn liggen kan worden opgemaakt dat afgestudeerden de relatief kritischere houding van studenten in het laatste leerjaar grotendeels delen. De stap naar de arbeidsmarkt lijkt men echter niet nog kritischer te maken. Weliswaar liggen een aantal van deze oordelen nog boven de diagonaal, waaruit blijkt dat men met name op het oordeel over de voorbereiding op de arbeidsmarkt gemiddeld een stuk negatiever is geworden. Er is echter ook een aantal aspecten waarover men na afstuderen gemiddeld juist positiever over is geworden, zoals de meer "persoonlijke" kenmerken van docenten (zoals betrokkenheid en inspirerend vermogen). Dit gedifferentieerde beeld is interessant, omdat het lijkt te suggereren dat de "reality check" van de transitie meer teweeg brengt dan een algehele tendens om negatiever te oordelen over de opleiding in algemene zin. Het feit dat er aanpassingen in oordelen zijn die in beide richting gaan, lijkt een indicatie te zijn van een meer weloverwogen reflectie over de kwaliteit van de opleiding. Op sommige punten blijken de opleiding door de bank genomen achteraf mee te vallen, en op andere aspecten juist iets tegen.

Deze vergelijking tussen studenten- en afgestudeerdenoordelen voor het hbo als geheel, is natuurlijk nog heel algemeen. We mogen aannemen dat er op het niveau van de betreffende onderzoekseenheden (in dit geval specifieke opleidingen aan specifieke hogescholen in het afstudeerjaar 2015) veel variatie bestaat in zowel studenten- als afgestudeerdenoordelen. Een van de belangrijkste vragen in het kader van dit onderzoek is hoe deze "lokale"variaties zich tot elkaar verhouden. Met andere woorden: in hoeverre zijn eenheden die door studenten als subtantieel onder- of bovengemiddeld worden beoordeeld, ook door afgestudeerden als onder- of bovengemiddeld aangemerkt? Vanuit het perspectief van de gebruikers van deze informatie lijkt een tamelijk sterke samenhang tussen oordelen van studenten en afgestudeerden wenselijk: hoe moet men immers reageren als studenten lovend zijn over (bijvoorbeeld) de docenten, en afgestudeerden zeer kritisch? Wie moet men dan geloven? Om hier meer duidelijkheid over te krijgen, bekijken we in figuur 2.4 de correlaties tussen HBO-Monitor- en NSE-oordelen. Omdat we vermoeden dat de vraagvorm hierop van invloed zou kunnen zijn, maken we hierbij onderscheid tussen oordelen met een nagenoeg identieke vraagstelling en antwoordschaal, oordelen met een afwijkende vraagstelling, en oordelen met een afwijkende antwoordschaal. 
FIGUUR 2.4 Correlaties tussen HBO-Monitor en NSE-oordelen

Studie in het algemeen

Voorbereiding beroepsloopbaan

Studiebegeleiding

Inhoudelijke deskundigheid docenten

Didactische kwaliteit docenten

Betrokkenheid docenten

Opleiding aanraden

Praktijkgericht onderzoek

Aansluiting actuele ontwikkelingen

Inhoudelijke samenhang

Docenten inspirerend

Kennis docenten over beroepspraktijk

Schriftelijk rapporteren praktijkgericht. onderzoek

M\&T praktijkgericht onderzoek

Beoordelingscriteria

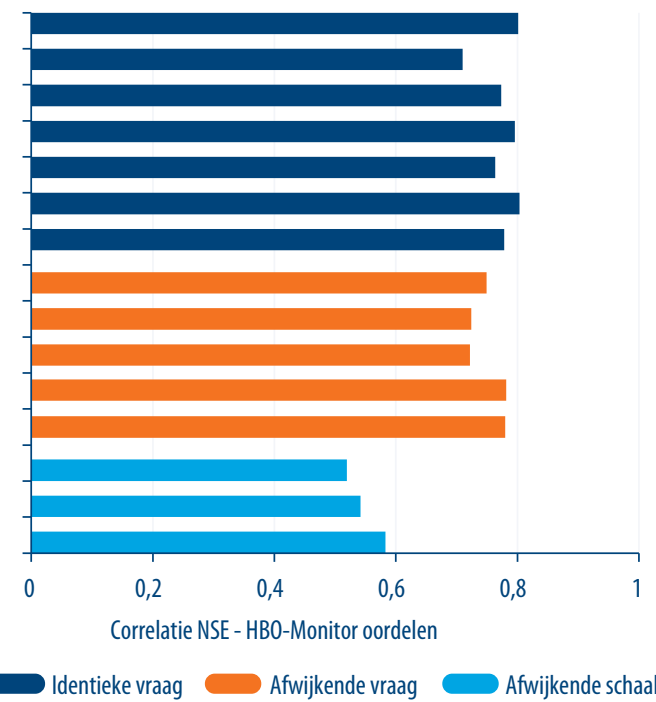

Over de gehele linie zijn de correlaties opvallend hoog, vooral gegeven het feit dat het om geaggregeerde gegevens uit twee verschillende bronnen gaat. Dit resultaat is op zichzelf al een sterke validering van zowel de HBO-Monitor als de NSE. De validiteit van beide studies wordt namelijk wel eens in twijfel getrokken, omdat het om subjectieve beoordelingen gaat waarbij een flink deel van de populatie (non-respondenten) buiten beschouwing is gebleven. Uit deze correlaties komt echter een zeer consistent beeld naar voren. Dit is goed nieuws voor gebruikers van de data, omdat het suggereert dat de uitkomsten robuust en betrouwbaar zijn.

Uit figuur 2.4. blijkt tevens dat de precieze vraagformulering niet zo veel uit lijkt te maken voor de vergelijkbaarheid: bij alle oordelen waarbij dezelfde schaal is gebruikt (in de meeste gevallen een 5-puntsschaal variërend van "zeer ontevreden" tot "zeer tevreden"), zien we correlaties van tussen de o,7 en o,8. Uit de lagere correlaties bij de onderste drie oordelen blijkt dat het wel belangrijk is om eenzelfde antwoordschaal te gebruiken. Zelfs hier worden correlaties van boven de 0,5 gehaald, wat behoorlijk sterk kan worden genoemd. Er lijkt dus een tamelijk sterke conceptuele overeenkomst te zijn tussen oordelen door studenten en afgestudeerden.

\section{Hoe stabiel zijn oordelen in de tijd?}

Een andere manier om naar de robuustheid en betrouwbaarheid van de uitkomsten te kijken, is door de ontwikkelingen in de tijd te bekijken. Figuur 2.5 toont trends in een selectie oordelen. Als vergelijkingskader worden hier nogmaals ook de NSE-oordelen van alle bachelor-studenten getoond, naast de oordelen van bachelors in het laatste jaar 
van hun opleiding en van afgestudeerden ruim een jaar na het verlaten van de opleiding.

FIGUUR 2.5 Trends in geselecteerde oordelen
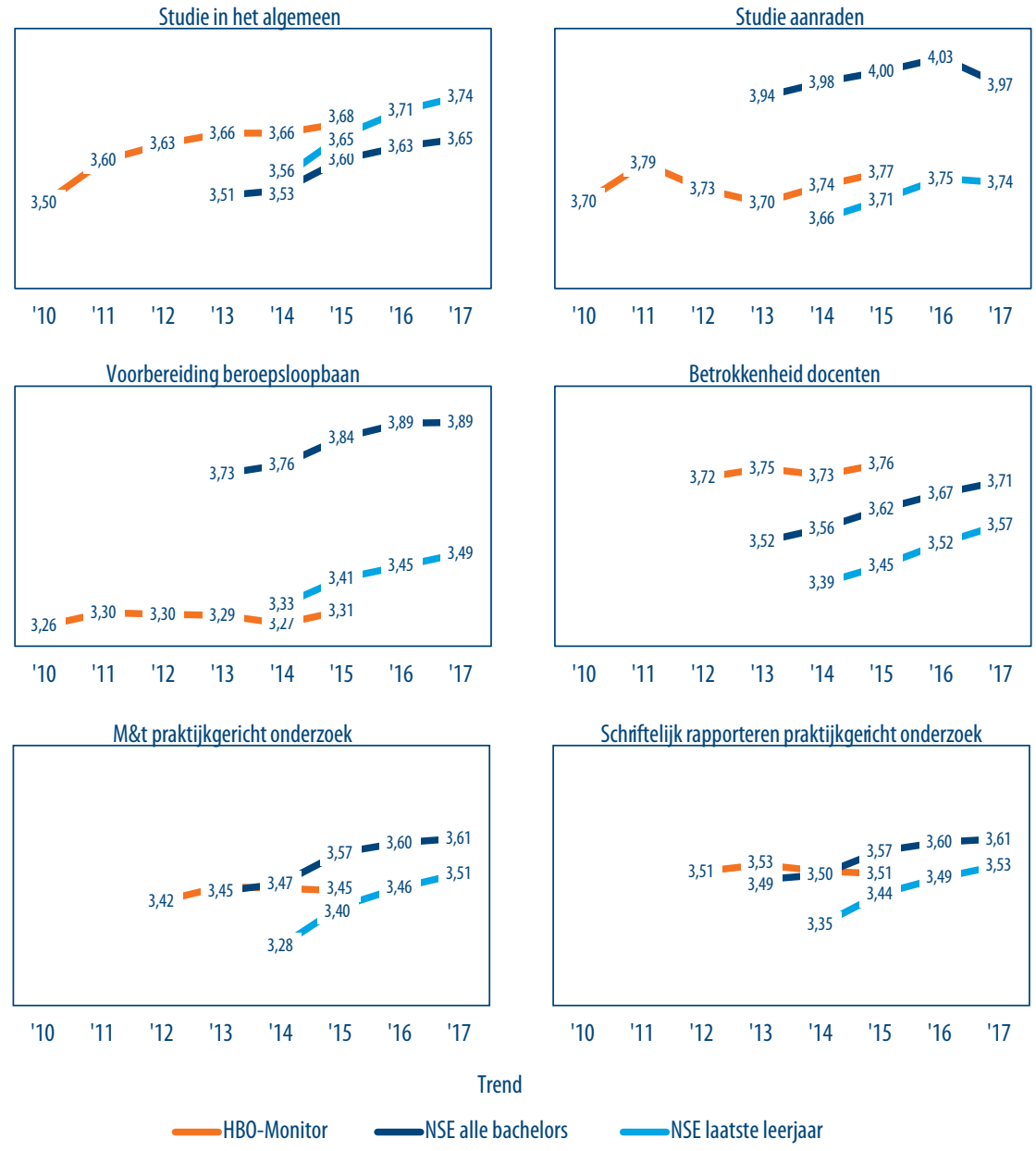

Helaas is sprake van slechts zeer beperkte overlap in de tijd tussen de HBO-Monitor en NSE. Wat we wel zien is dat sommige oordelen doorheen de tijd veranderen, maar dat deze veranderingen relatief gradueel zijn, en vaak een stabiele trend laten zien over een aantal uitstroomjaren. Voor zover als de overlap het toestaat, lopen de veranderingen onder studenten en afgestudeerden vaak in dezelfde richting. Uitzonderingen hierop zijn twee oordelen over specifieke vaardigheden die op afwijkende antwoordschalen zijn gebaseerd, namelijk "methoden en technieken van praktijkgericht onderzoek" en "schriftelijk rapporteren over praktijkgericht onderzoek". In de HBO-Monitor zijn deze indicatoren niet gemeten op de gebruikelijke tevredenheidsschaal dat in de NSE (en 
ook elders in de HBO-Monitor) wordt gebruikt, maar op zelfinschattingen door afgestudeerden van hun eigen vaardigheden. Deze zelfinschattingen lijken niet veel te veranderen in de tijd, terwijl de tevredenheid van studenten over deze aspecten in de loop der jaren duidelijk vooruitgaat. Dit verschil zou kunnen worden verklaard door het feit dat oordelen veel sneller kunnen veranderen dan verworven vaardigheden.

\section{Hoe ziet de samenhang eruit op het niveau van instellingen en opleidingen?}

We kunnen de samenhang ook visueel bekijken op het niveau van hbo-instellingen en -opleidingen. Dit zijn ook de niveaus waarop de oordelen in de praktijk worden vergeleken. Figuur 2.6 toont de vergelijkingen van een selectie oordelen naar hbo-instelling. Het gaat hierbij om de gemiddelde afwijkingen van algemene opleidingsgemiddelden. Hierdoor wordt een tamelijk zuiver beeld verkregen van de mate waarop instellingen die vergelijkbare opleidingen aanbieden, systematisch anders worden beoordeeld. leder bolletje representeert een instelling.

FIGUUR 2.6 Relatie tussen HBO-Monitor en NSE-oordelen op niveau van instellingen
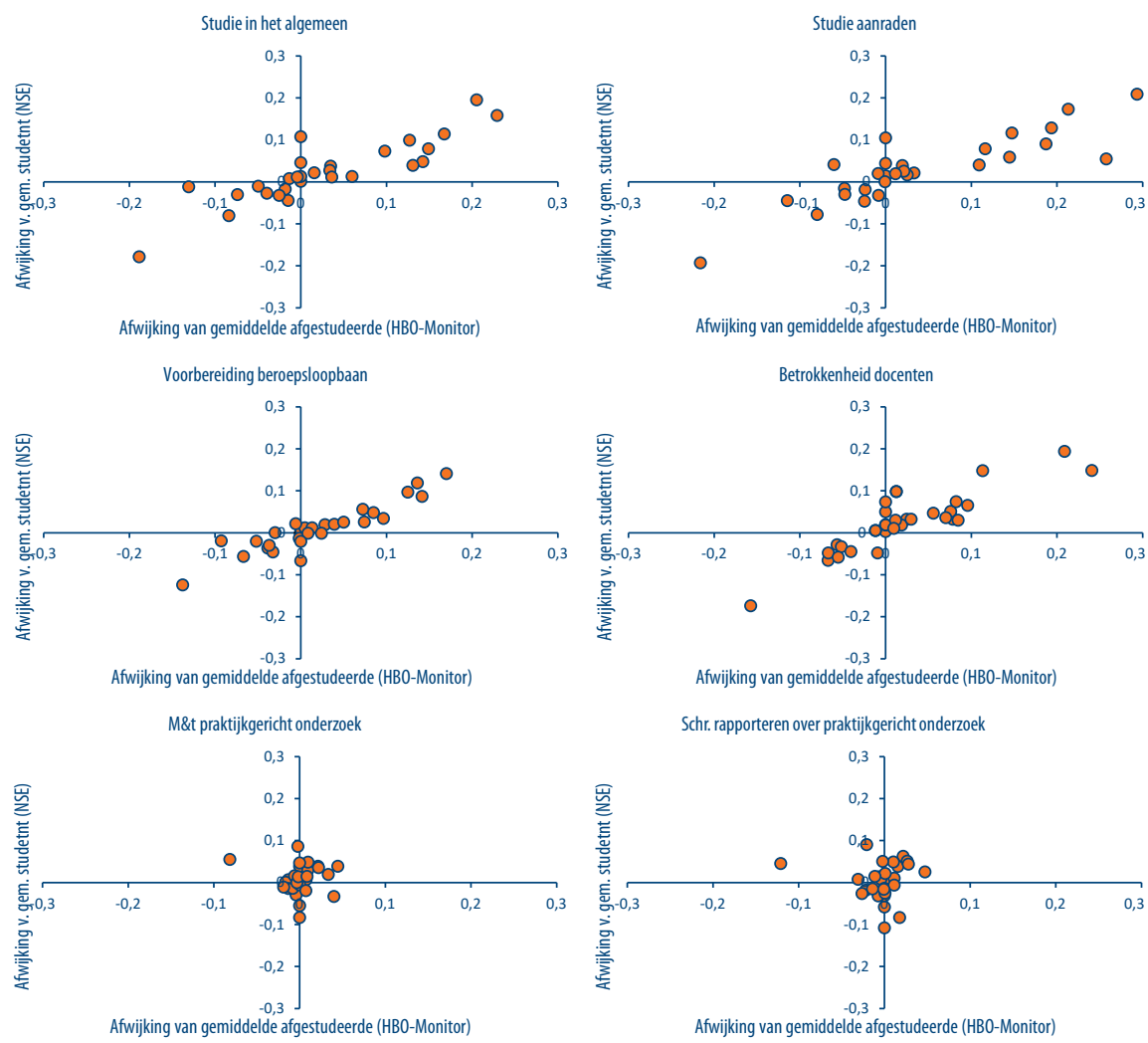
Uit figuur 2.6 komt naar voren dat instellingen vrij consistent worden beoordeeld door studenten en afgestudeerden. Op de meeste aspecten worden instellingen die door studenten als boven- of ondergemiddeld worden beoordeeld, dat later ook nog door afgestudeerden. Er blijken voor deze aspecten erg weinig spreiding te zijn tussen instellingen in afgestudeerdenoordelen. Hierdoor is weinig of geen samenhang te zien tussen HBO-Monitor en NSE oordelen op deze aspecten.

Figuur 2.7 toont dezelfde vergelijking op het niveau van landelijk gedefinieerde opleidingen ( $\mathrm{CROHO}$ ). Ook hier worden ter wille van de overzichtelijkheid, alle oordelen afgezet tegen een algemeen gemiddelde, ditmaal het gemiddelde van het hbo als geheel.

FIGUUR 2.7 Relatie tussen HBO-Monitor en NSE-oordelen op niveau van opleidingen
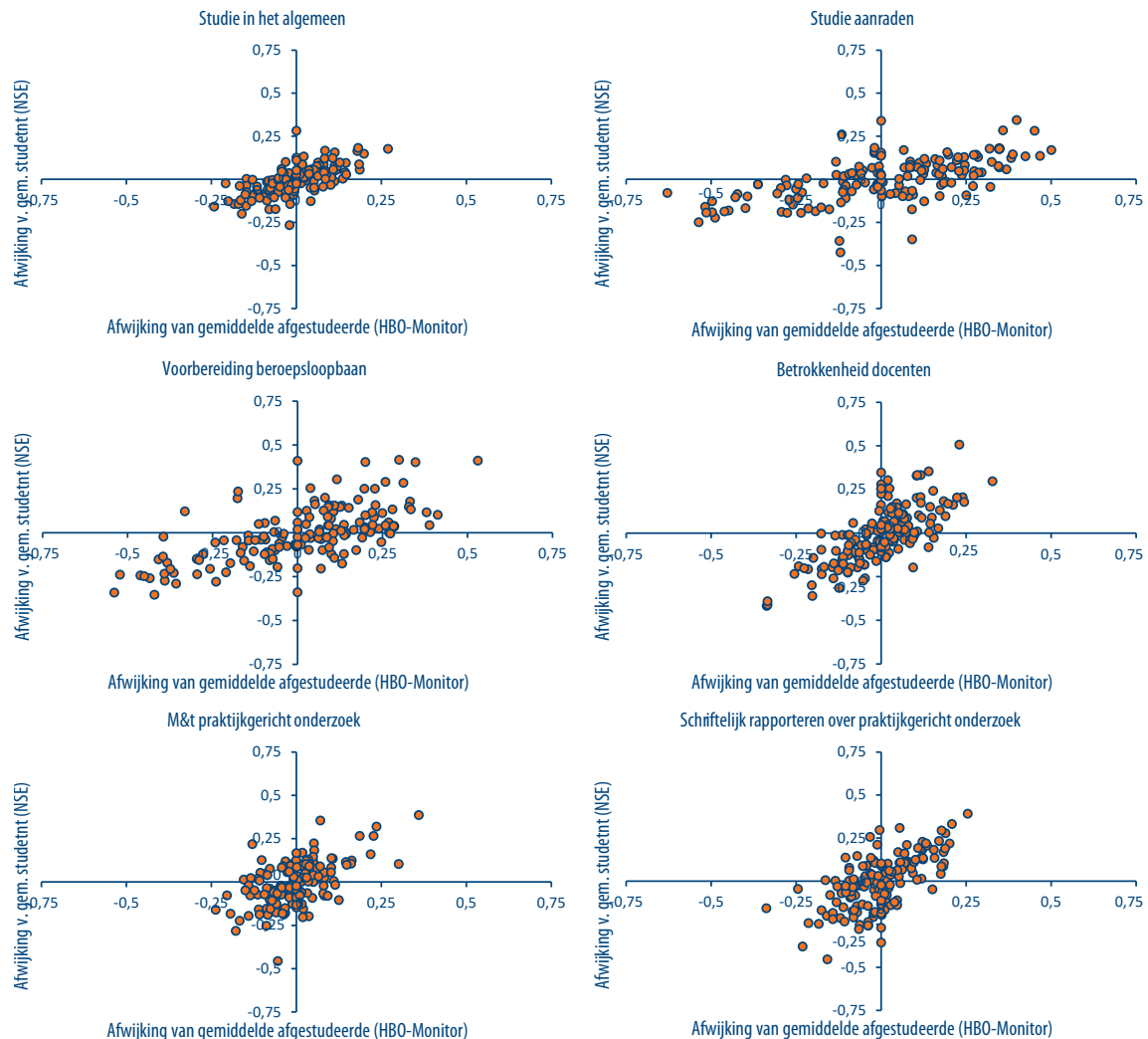

Uit figuur 2.7 blijkt dat ook opleidingen vrij consistent worden beoordeeld door studenten en door afgestudeerden. Wel is er sprake van veel meer spreiding in de oordelen, vooral onder de afgestudeerden. Met andere worden: de meningen van afgestudeerden over de kwaliteit van de opleiding liggen verder uit elkaar dan de meningen van studenten. 
Nogmaals blijken de zelf-gerapporteerde competenties in de HBO-Monitor minder spreiding te vertonen dan de overige oordelen. Echter, ook bij deze oordelen is een duidelijke overeenkomst te bespeuren tussen de oordelen van afgestudeerden en die van studenten.

\section{Individuele variantie}

Tot nu toe zijn we ervan uitgegaan dat oordelen betrekking hebben op opleidingen en instellingen als geheel. Hierbij werd er impliciet van uitgegaan dat individuele oordelen min of meer random zijn verdeeld rondom de gemiddelden van de eenheden waartoe ze behoren, en dat deze gemiddelden de "ware" waarden van de eenheden weergeven. Deze conceptualisatie deed recht aan het doel van de oordeelsvragen, namelijk: een beeld vormen van de relatief sterke en zwakke punten van de opleiding als geheel. Het is echter niet vanzelfsprekend dat alle studenten c.q. afgestudeerden van een bepaalde opleiding dezelfde mening is toegedaan. Het is denkbaar dat oordelen bij vergelijkbare opleidingen systematisch verschillen naar kenmerken als geslacht, leeftijd, etniciteit en vooropleiding. Als bijvoorbeeld vrouwen systematisch positiever of negatiever oordelen over dezelfde opleidingen dan hun mannelijk studiegenoten, zou dit een potentiele bron van bias kunnen zijn, wanneer deze kenmerken verschillend zouden zijn verdeeld over vergelijkbare eenheden. Om na te gaan in hoeverre er sprake zou kunnen zijn van dit soort bias wordt hieronder een overzicht geboden van de relatie tussen deze kenmerken en individuele oordelen. Omdat het NSE- bestand geen algemeen beschikbare achtergrondinformatie bevat, kan deze exercitie alleen worden toegepast bij de HBO-Monitor.

Figuur 2.8 toont de verschillen in oordelen naar geslacht en leeftijd. Hieruit blijkt dat vrouwen en mannen niet zo veel van elkaar verschillen in hun oordelen: op geen enkel aspect is het absolute verschil groter dan ééntiende van een schaalpunt. Ook leeftijd lijkt niet al te veel uit te maken: vijf jaar ouder zijn, gaat gepaard met maximaal ééntiende schaalpunt verschil. Interessant hierbij is wel dat in het geval van leeftijd alle verschillen in dezelfde richting wijzen: oudere afgestudeerden zijn iets kritischer over de opleiding. De omvang van de verschillen zijn echter niet dusdanig groot dat hiervan een belangrijke vertekening wordt verwacht. 
FIGUUR 2.8 Verschillen in HBO-Monitor oordelen naar geslacht en leeftijd
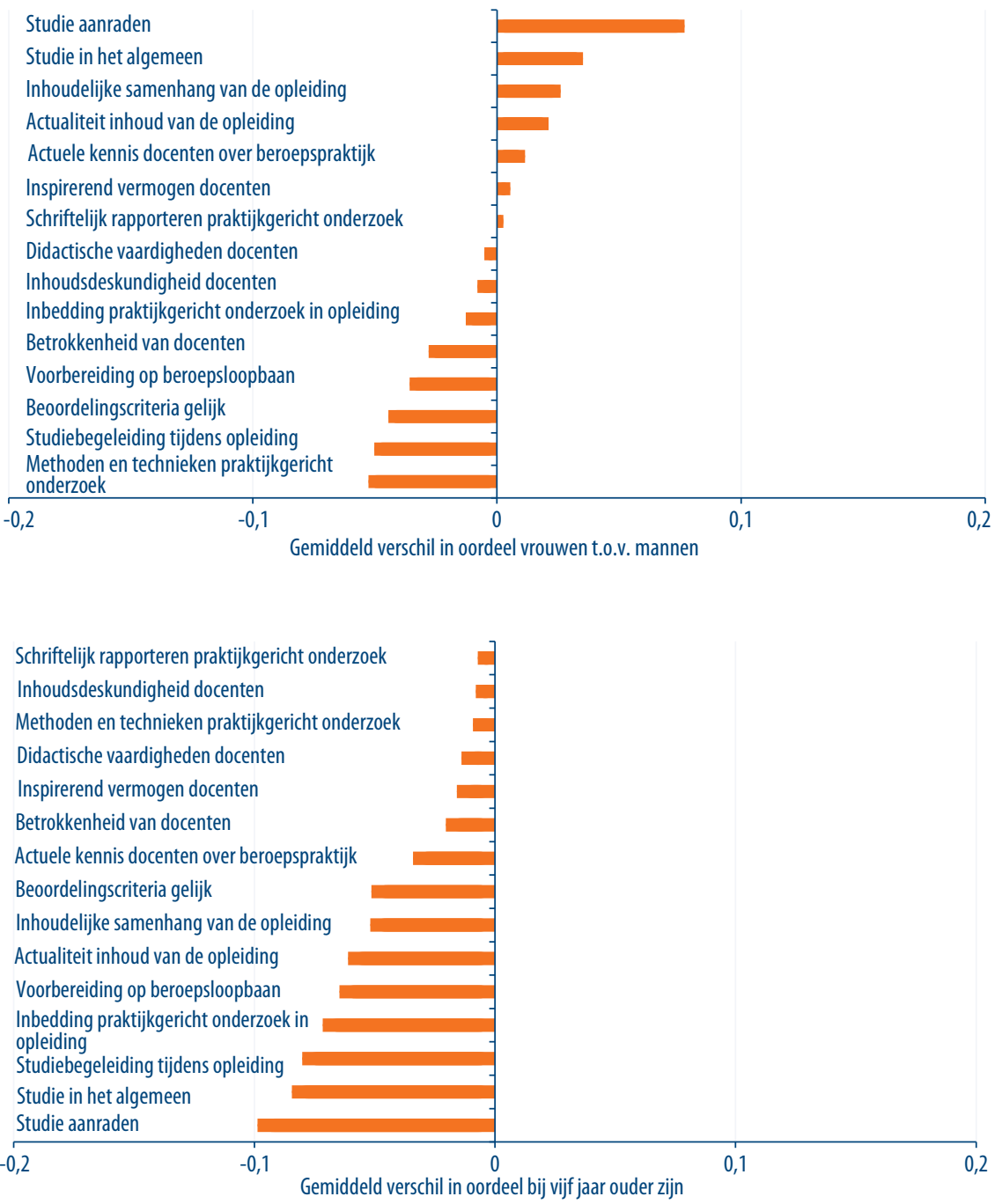

Figuur 2.9 laat zien dat ook de verschillen naar etniciteit vrij klein zijn. Afgestudeerden met een niet-westerse achtergrond schatten hun specifieke competenties iets hoger in ook zijn zij iets minder te spreken over de betrokkenheid van de docenten. Ook hierbij is geen reden om te verwachten dat dit tot grote vertekeningen in de resultaten leidt. 
FIGUUR 2.9 Verschillen in HBO-Monitor oordelen naar etniciteit

Schriftelijk rapporteren praktijkgericht onderzoek Methoden en technieken praktijkgericht onderzoek Didactische vaardigheden docenten Beoordelingscriteria gelijk

Actuele kennis docenten over beroepspraktijk Inbedding praktijkgericht onderzoek in opleiding Inhoudsdeskundigheid docenten Studie in het algemeen

Voorbereiding op beroepsloopbaan Studiebegeleiding tijdens opleiding Actualiteit inhoud van de opleiding Inspirerend vermogen docenten Inhoudelijke samenhang van de opleiding Studie aanraden

Betrokkenheid van docenten

$$
\begin{aligned}
& -0,1 \\
& \text { Gemiddeld verschil in oordeel t.o.v. geen migratieachtergrond } \\
& \\
& \begin{array}{l}
\text { Niet-westerse } \\
\text { migratieachtergrond }
\end{array}
\end{aligned}
$$

Uit figuur 2.10 blijkt dat vooropleiding een iets sterker rol speelt dan bovengenoemde persoonskenmerken: met name mensen die op basis van een mbo-vooropleiding zijn ingestroomd, zijn iets positiever over de gevolgde opleiding. Ook hier is de omvang van het verschil dusdanig klein dat er een fors verschil tussen eenheden in mbo-instroom nodig zou zijn om een noemenswaardige vertekening op te leveren. In het meest extreme geval zou bij vergelijkbare eenheden een verschil van $25 \%$ versus $75 \%$ mboinstroom, tot niet meer dan 0,1 schaalpunt verschuiving in het gemiddeld oordeel leiden.

FIGUUR 2.10 Verschillen in HBO-Monitor oordelen naar vooropleiding

Studie aanraden

Studie in het algemeen

Voorbereiding op beroepsloopbaan

Studiebegeleiding tijdens opleiding

Inspirerend vermogen docenten

Inhoudelijke samenhang van de opleiding

Didactische vaardigheden docenten

Betrokkenheid van docenten

Inhoudsdeskundigheid docenten

Actuele kennis docenten over beroepspraktijk

Beoordelingscriteria gelijk

Schriftelijk rapporteren praktijkgericht onderzoek

Actualiteit inhoud van de opleiding

Methoden en technieken praktijkgericht onderzoek

Inbedding praktijkgericht onderzoek in opleiding
$-0,1$

Gemiddeld verschil in oordeel t.o.v. havo vooropleiding

Vooropleiding:MBO Vooropleiding: VWO

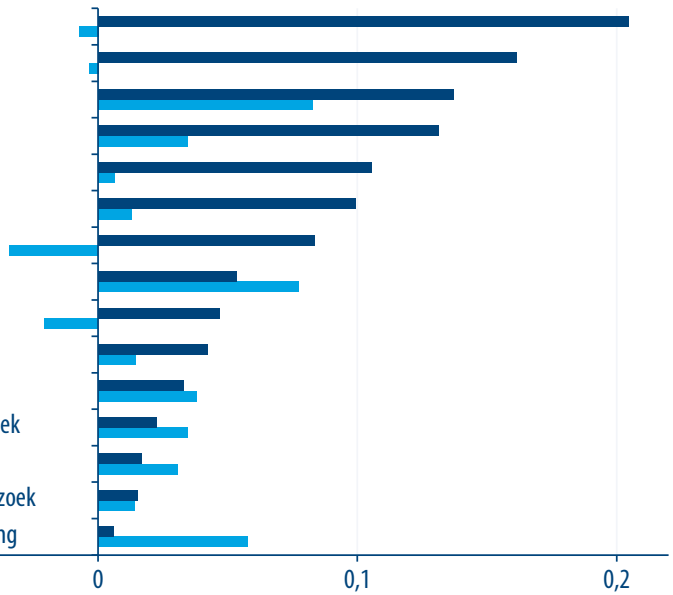

0,2 



\section{3 \\ NADERE ANALYSE VAN VERSCHILLEN TUSSEN HBO-MONITOR EN NSE}

In de vorige paragraaf zagen we dat er een sterke samenhang bestaat op geaggregeerd niveau tussen de oordelen van studenten in het laatste studiejaar van de hbo-opleiding en de oordelen van recent afgestudeerden van dezelfde opleidingen en instellingen. Toch zijn de correlaties niet perfect. Met het oog op een goede interpretatie en gebruik van de resultaten van beide onderzoeken is van belang om zicht te hebben op de punten waarop ze van elkaar verschillen, en op kenmerken en ervaringen van afgestudeerden die met deze verschillen samenhangen. In deze paragraaf verplaatsen we daarom de focus van overeenkomsten tussen HBO-Monitor en NSE naar verschillen tussen de twee onderzoeken. Omdat de geaggregeerde oordelen van zowel studenten als afgestudeerden gebaseerd zijn op antwoorden op basis van vergelijkbare - in de meeste gevallen zelfs identieke - 5 -puntsschalen, kunnen we per eenheid zulke verschillen nauwkeurig vaststellen. Figuur 3.1 vat deze verschillen samen.

\section{FIGUUR 3.1 Verschuiving in oordelen tussen NSE en HBO-Monitor}

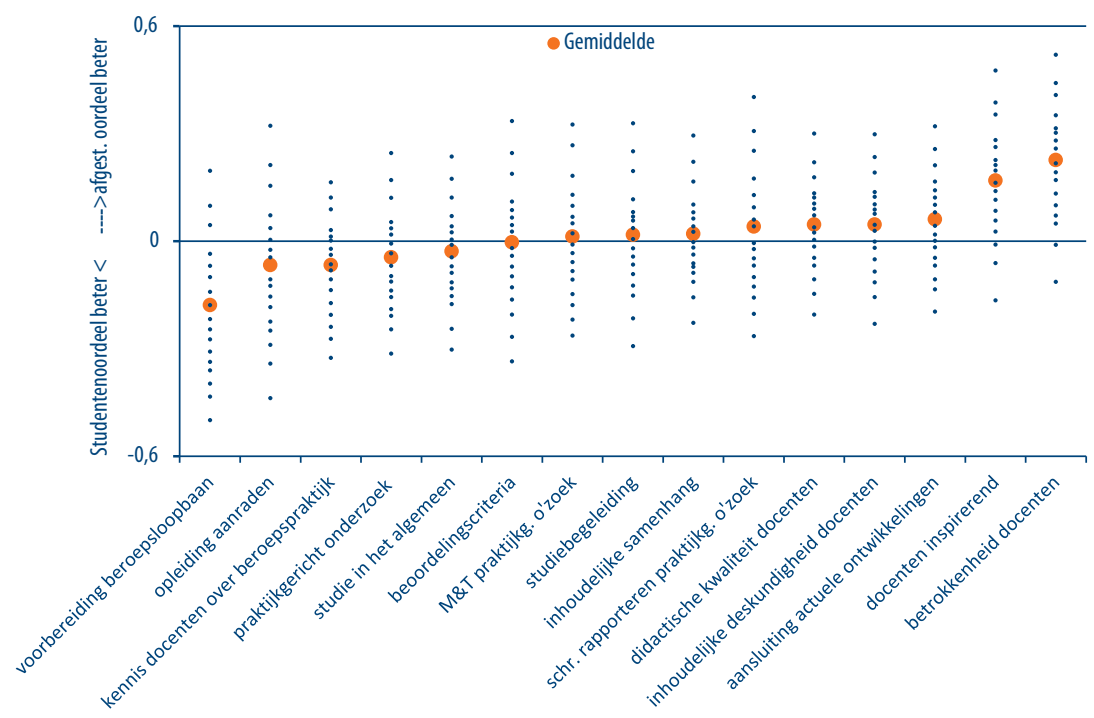


Figuur 3.1 toont voor het hbo als geheel het gemiddelde (de rode stipjes) van de verschuiving in de 15 oordelen tussen de NSE meting en de HBO-Monitor, evenals de spreiding in deze verschuiving onder de eenheden in de onderzoeken (instelling $\mathrm{X}$ opleiding: de zwarte stipjes)). Bij een perfecte overeenkomst tussen NSE en HBO-Monitor zou de verschuiving in alle gevallen precies nul zijn. In dat geval zouden alle punten op de nullijn samenvallen. Punten boven de nullijn geven eenheden aan waarbij het oordeel van afgestudeerden positiever is dan dat van studenten, terwijl punten onder de nullijn eenheden aangeven waarbij men gemiddeld negatiever is gaan oordelen.

Wat het gemiddelde betreft, liggen de meeste punten dicht bij de nullijn. De belangrijkste uitzonderingen hierop betreffen het oordeel over de voorbereiding op de beroepsloopbaan, dat gemiddeld een stuk achteruit is gegaan, en een tweetal oordelen over docenten, die over de hele linie duidelijk zijn verbeterd. Wanneer we echter naar de verschuiving per eenheid kijken, blijkt voor alle oordelen sprake te zijn van een aanzienlijke spreiding. Hieruit blijkt dat zelfs op oordelen die gemiddeld vooruit zijn gegaan, er eenheden zijn waar het oordeel achteruit is gegaan, en andersom.

Het is overigens meestal niet zo dat als gevolg van deze verschuivingen het gemiddelde oordeel voor een gegeven eenheid omslaat van zeer positief naar zeer negatief of andersom. In de overgrote meerderheid van de gevallen, is de verschuiving minder dan éénderde van een schaalpunt. Een dergelijke verschuiving is zeker niet verwaarloosbaar, maar kan beter worden geïnterpreteerd als een bijstelling van het oorspronkelijk oordeel - bijvoorbeeld: de studiebegeleiding was bij nader inzien iets beter dan dat we tijdens de studie dachten - dan een radicale correctie. Zelfs in de meest extreme gevallen is de verschuiving consistent met een situatie waar bijvoorbeeld de helft van de respondenten hun oordeel van "enigszins tevreden" in "neutraal" veranderden of andersom.

Een belangrijke vraag is in hoeverre de verschuivingen samenhangen met ervaringen na het verlaten van de opleiding. Wanneer de verschuiving aantoonbaar samenhangt met ervaringen die zijn opgedaan na het verlaten van de opleiding, zou dat een indicatie kunnen zijn van voortschrijdend inzicht. De meest voor de hand liggende bron van verandering in oordeel is de mate van succes op de arbeidsmarkt sinds afstuderen. De meeste studenten zullen tijdens de opleiding de wens hebben een goede baan te vinden na afstuderen. Wanneer een bepaalde opleiding boven- of ondergemiddeld presteert in termen van arbeidsmarktrendement, ligt het voor de hand dat afgestudeerden met iets andere ogen terugkijken op de opleiding. Om deze verwachting te toetsen is een samengestelde arbeidsmarktsuccesindicator geconstrueerd per eenheid, gebaseerd op kans op werk, aansluiting naar niveau, uurloon en baantevredenheid. Figuur 3.2 toont de relatie tussen deze indicator met het gemiddeld oordeel van studenten, van afgestudeerden, en de verschuiving tussen deze twee. ${ }^{2}$

2 In theorie hadden we afzonderlijke maten kunnen construeren voor de verschillende dimensies van arbeidsmarktsucces. Het is echter duidelijk dat dit tot een explosie in het aantal getoonde tabellen of figuren zou hebben geleid. Uit oogpunt van overzichtelijkheid is met één samengestelde maat gewerkt. Als robuustheidscheck hebben we de hier gepresenteerde analyses ook verricht met de afzonderlijke succesmaten als voorspeller van verschuivingen. Een aantal accentverschillen daargelaten, zijn de resultaten van deze analyses goed vergelijkbaar met de getoonde resultaten. 
FIGUUR 3.2 Correlaties van HBO-Monitor- en NSE-oordelen en -verschuivingen met arbeidsmarktsucces van opleidingen en instellingen

Voorbereiding beroepsloopbaan

Opleiding aanraden

Studiebegeleiding

Inhoudelijke samenhang

Inhoudelijke deskundigheid docenten

Studie in het algemeen

Betrokkenheid docenten

Docenten inspirerend

Didactische kwaliteit docenten

M\&T praktijkg. onderzoek

Praktijkgericht onderzoek

Kennis docenten over beroepspraktijk

Aansluiting actuele ontwikkelingen

Beoordelingscriteria

Schriftelijk rapporteren praktijkgericht onderzoek

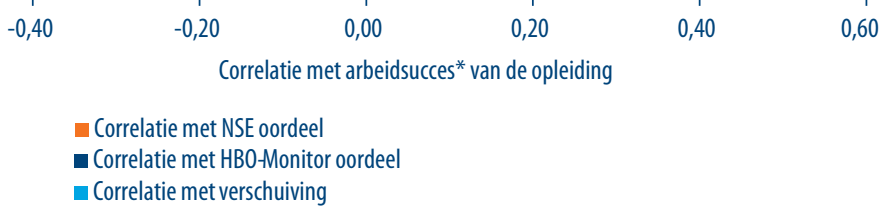

* Aggregaatindex gebaseerd op kans op werk, aansluiting naar niveau, uurloon en baantevredenheid

We zien dat het oordeel van zowel studenten als afgestudeerden over de voorbereiding op de arbeidsmarkt samenhangt met het arbeidsmarktsucces van de betreffende eenheid, en dat de verschuiving in dit oordeel ook daarmee samenhangt. We kunnen hieruit alvast een aantal voorlopige conclusies trekken. Ten eerste, blijkt het studentenoordeel al een zekere voorspellende waarde te hebben gehad in termen van arbeidsmarktsucces. Ten tweede, blijkt dat afgestudeerden van succesvolle opleidingen hun mening op dit punt verder bijstellen. Ten slotte, zien we dat door deze verschuiving de samenhang van arbeidsmarktsucces met het oordeel van afgestudeerden nog sterker is dan de samenhang met het oordeel van studenten.

In het geval van de bereidheid om de studie aan te raden aan anderen is er ook een sterke relatie tussen arbeidsmarktsucces en het oordeel van afgestudeerden, maar niet met het studentenoordeel. De relatie van arbeidsmarktsucces met de bereidheid de opleiding aan te raden aan anderen is dus in het geheel gedreven door de opgedane ervaringen op de arbeidsmarkt sinds afstuderen.

Andere oordelen van zowel studenten als afgestudeerden hangen hooguit zwak tot matig samen met arbeidsmarktsucces. Bij inhoudelijke samenhang van de opleiding, en in iets mindere mate de studie in het algemeen, is echter sprake van een duidelijk verband met de verschuiving, waardoor de relatie met afgestudeerdenoordelen sterker 
is dan met studentenoordelen. Hieruit blijkt dat, hoewel de oordelen van studenten en afgestudeerden op deze punten niet structureel worden bepaald door arbeidsmarktsucces, er sprake is van een zekere bijstelling van bepaalde oordelen op basis van de mate van succes.

Bij de overige oordelen is de relatie met arbeidsmarktsucces dusdanig zwak dat we er weinig inhoudelijke betekenis aan kunnen geven. Bij één oordeel - over de beoordelingscriteria - is zelfs een negatieve relatie met de verschuiving te zien. Omdat er geen aannemelijk mechanisme is om een dergelijke relatie te verklaren gaan we er hierbij van uit dat het een schijneffect is, mogelijk samenhangend met het feit dat er bij de HBO-Monitor een andere antwoordschaal is gebruikt dan bij de NSE.

Een ander aspect van de transitie dat mogelijk een effect op oordelen heeft is de doorstroom naar vervolgonderwijs. Figuur 3.3 geeft hiervan een overzicht.

FIGUUR 3.3 Correlaties van HBO-Monitor-en NSE-oordelen en -verschuivingen met doorstroom afgestudeerden naar vervolgonderwijs

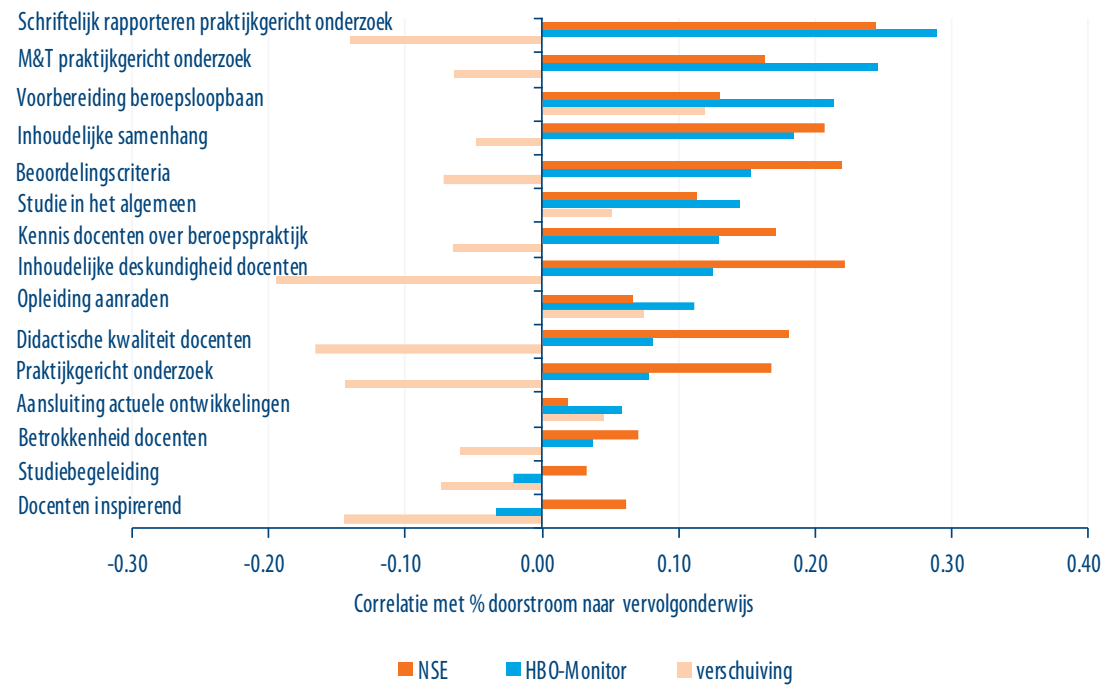

Opvallend is dat studenten van opleidingen waarvan blijkt dat er een sterke doorstroom naar vervolgonderwijs is, op een aanzienlijk aantal punten positiever zijn over hun opleiding dan studenten van opleidingen waarvan de doorstroom naar vervolgonderwijs lager ligt. lets vergelijkbaars geldt voor de relatie met afgestudeerdenoordelen, al is deze relatie veel sterker bij sommige oordelen dan bij anderen.

Uit figuur 3.3 blijkt tevens dat de doorstroom op veel punten negatief samenhangt met de verschuiving in oordelen, vooral de oordelen over docenten en over praktijkgericht 
onderzoek in de opleiding. Dat men minder positief over deze aspecten is gaan denken zou wellicht toe te schrijven kunnen zijn aan het feit dat een vervolgopleiding een nieuwe maatstaf/vergelijkingskader schept. Het is ook mogelijk dat de groep afgestudeerden die na afronding van een vierjarige hbo-bachelor opleiding besluit nog verder te gaan met onderwijs, een heel specifieke groep is, die een heel bewuste keuze heeft gemaakt om verder te studeren. Wellicht vormt voor een deel van deze doorstudeerders ontevredenheid met aspecten van de initiële hbo-opleiding een deel van de motivatie om door te studeren.

De gedifferentieerde reactie van afgestudeerden op arbeidsmarktsucces en doorstuderen kan worden opgevat als indicatie van voortschrijdend inzicht. Op basis van specifieke ervaringen op de arbeidsmarkt en/of in het vervolgonderwijs, worden specifieke oordelen na afstuderen bijgesteld en anderen niet. Het is echter niet uit te sluiten dat afgestudeerden die positieve dan wel negatieve ervaringen opdoen na afstuderen, deze ervaringen "projecteren" op de gevolgde opleiding. In dat geval is het niet zozeer dan afgestudeerden door hun ervaringen tot een beter inzicht in de opleiding komen, maar eerder dat ze de opleiding de schuld geven voor hun teleurstellende resultaten op de arbeidsmarkt. Toch lijkt deze omgekeerde verklaring niet zo plausibel. Waarom zou men hun teleurstelling met de bereikte resultaten op de arbeidsmarkt zo sterk projecteren op de voorbereiding en de bereidheid om de opleiding aan te raden, en veel minder of zelfs helemaal niet op de docenten, de aansluiting met de beroepspraktijk of de studie in het algemeen?

Als een verdere check op de mate waarin oordelen van afgestudeerden voornamelijk door de eigen mate van arbeidsmarktsucces worden bepaald, kunnen we naar de voorspellingswaarde van de arbeidsmarktsucces van dezelfde eenheden in eerdere uitvoeringsjaren op de oordelen over de opleiding door de huidige cohort. Er kan immers dan geen directe relatie meer zijn tussen arbeidsmarktsucces en oordelen, omdat het niet meer om het eigen arbeidsmarktsucces gaat, maar van dat van afgestudeerden van dezelfde opleidingen uit eerdere cohorten. Het succes van opleidingen op de arbeidsmarkt toont wel een sterke correlatie over meetjaren, in de buurt van o,85 tussen de drie afgelopen meetjaren. Door voorspellingen gebaseerd op het actuele uitstroomjaar te vergelijken met voorspellingen op basis van data van eerdere jaren, kunnen we enig "feeling" krijgen voor de mate waarin de cijfers vooral door eigen ervaringen zijn gedreven, en in hoeverre de algemene resultaten van eenheden als geheel bepalend zijn. Wanneer we soortgelijke relaties terugzien met gemiddelden van eerdere uitstroomjaren - waartoe de betreffende afgestudeerden min of meer per definitie niet toe behoren - zou dit een indicatie zijn dat verschuivingen meer door het succes van de opleiding als geheel worden gedreven dan door individuele arbeidsmarktresultaten..

Om te beginnen toont figuur 3.4 het effect van arbeidsmarktsucces van opleidingen op gemiddelde oordelen van dezelfde opleidingen in hetzelfde uitstroomjaar. De arbeidsmarktsuccescijfers hebben dus betrekking op precies dezelfde uitstroomcohorten die de oordelen leverden. Om te kijken of er een additioneel effect is voor opleidingen waar- 
voor een verbetering te zien is, laten we ook het effect van het verschil in arbeidsmarktsucces per opleiding ten opzichte van het jaar daarvoor.

FIGUUR 3.4 Effect van arbeidsmarktsucces in 2015 en verschil in arbeidsmarktsucces t.o.v. 2014 op HBO-Monitor-oordelen in 2015

Studiebegeleiding

Inhoudelijke deskundigheid docenten M\&T praktijkgericht onderzoek

Inhoudelijke samenhang

Docenten inspirerend

Studie in het algemeen

Praktijkgericht onderzoek

Betrokkenheid docenten

Didactische kwaliteit docenten

Kennis docenten over beroepspraktijk

Aansluiting actuele ontwikkelingen

Schr. rapporteren praktijkgericht o'zoe

Beoordelingscriteria

$$
-0,30
$$

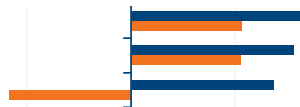

- Verschil 2014-2015

Voor wat betreft het effect van arbeidsmarktsucces komt uit figuur 3.4 het inmiddels bekende beeld naar voren: succes van een opleiding op de arbeidsmarkt gaat gepaard met beduidend betere beoordeling in termen van de voorbereiding op de arbeidsmarkt en de bereidheid de opleiding aan te raden, en toont wat zwakkere effecten op een beperkt aantal andere oordelen. Interessant is de bevinding dat de verschuiving in arbeidsmarktsucces ook een licht positief effect lijkt te hebben op een aantal oordelen. Dit effect is niet sterk, en dienen derhalve met voorzichtigheid te worden geïnterpreteerd (in twee gevallen is het effect juist licht negatief). Het lijkt echter alsof opleidingen die "in de lift" zijn, op een iets betere beoordeling kunnen rekenen in een aantal opzichten dan opleidingen die stilstaan of juist achteruit zijn gegaan.

In figuur 3.5 worden de effecten getoond van dezelfde analyses, waarbij data van 2015 worden vervangen met die van 2014. Let wel: het gaat hier dus niet meer om arbeidsgegevens van hetzelfde cohort, maar om arbeidsmarktgegevens van het cohort van een jaar eerder. Ook hier wordt het effect van verbetering t.o.v. een jaar eerder opgenomen. 
FIGUUR 3.5 Effect van arbeidsmarktsucces in 2014 en verschil in arbeidsmarktsucces t.o.v. 2013 op HBO-Monitor-oordelen in 2015

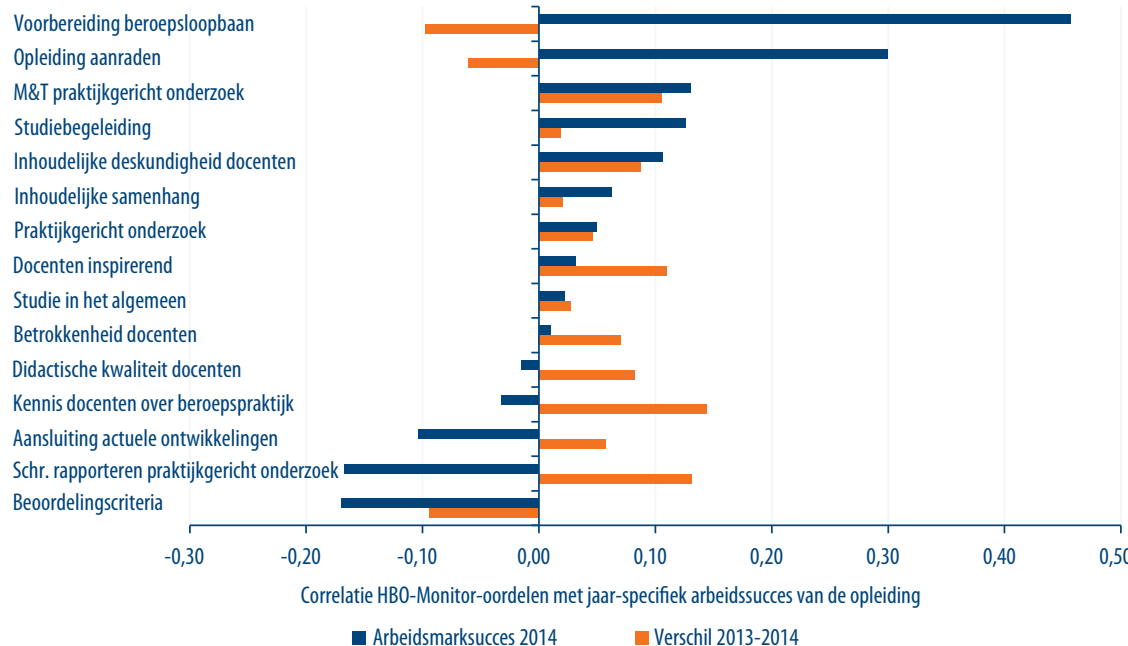

De hoofdeffecten van arbeidsmarktsucces zijn iets zwakker in dit geval, maar verder is het patroon hetzelfde. De voorspellende kracht van ervaringen van het cohort zelf wegen dus ook mee, maar het verschil is gering: de relatie wordt vooral gedreven door een sterk algemeen component dat structureel gekoppeld is aan de opleiding. Ook interessant is echter de bevinding dat een verbetering tussen 2013 en 2014 ook een vergelijkbaar effect op oordelen heeft als een verbetering tussen 2014 en 2015. De verbetering tussen 2013 en 2014 heeft helemaal niets te maken met het cohort dat de oordelen levert, en kan dus worden opgevat als een min of meer zuivere opleidingseffect. Het effect is klein en heeft betrekking op deels andere aspecten van de opleiding, waardoor enige voorzichtigheid wordt geboden bij het toekennen van een inhoudelijke interpretatie. De belangrijkste conclusie in termen van de huidige discussie is dat een eventueel effect van het verschil tussen opeenvolgende uitroomjaren helemaal niets te maken lijkt te hebben met de ervaringen van de afgestudeerden zelf.

Als laatste robuustheidscheck kunnen we tenslotte nog één jaar verder terug in de tijd gaan en data uit 2013 gebruiken om oordelen van cohort 2015 te voorspellen. We tonen de voorspellingen op basis van data van drie elkaar opvolgende cohorten in figuur 3.6. 
FIGUUR 3.6 Effect van arbeidsmarktsucces in 2013, 2014 en 2015 op HBO-Monitor-oordelen in 2015

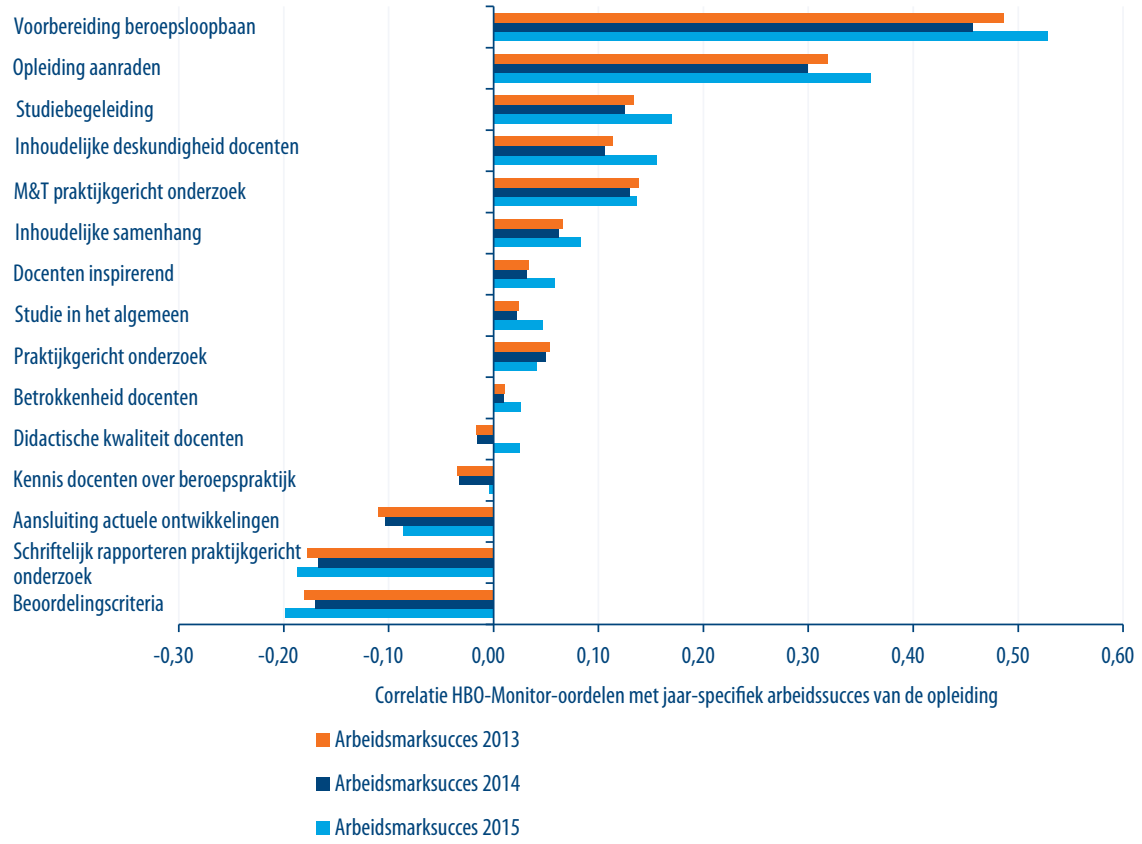

Er is een lichte verbetering in voorspellingkracht wanneer data van hetzelfde cohort wordt gebruikt dat de oordelen heeft geleverd, maar het verschil is klein. Er is geen overeenkomstige verbetering in voorspellingskracht van data uit 2014 t.o.v. data uit 2013 (2013 data lijken zelfs iets beter te voorspellen dan 2014 data). Hieruit kan de conclusie worden getrokken dat het effect van arbeidsmarktsucces op oordelen vooral met de opleiding te maken heeft, en slechts in geringe mate met de persoonlijke ervaringen van de afgestudeerden zelf. 


\section{4 \\ WAT VOEGT DE HBO-MONITOR TOE?}

Uit het voorgaande is gebleken dat er op geaggregeerd niveau sprake van een zeer sterke relatie is tussen oordelen van studenten tijdens de opleiding en die van afgestudeerden na de transitie naar de arbeidsmarkt. Dit betekent dat we al tamelijk veel weten over deze aspecten voordat de HBO-Monitor het veld ingaat. We weten inmiddels ook dat in een aantal gevallen de ervaringen na afstuderen - in het bijzonder de mate van arbeidsmarktsucces en de doorstroom naar vervolgonderwijs -met verschuivingen in oordelen samenhangen. Deze verschuivingen in oordelen zijn echter niet zonder meer te interpreteren als de "toegevoegde waarde" van de afgestudeerdenoordelen ten opzichte van de studentenoordelen. Kenmerkend van deze verschuivingen is immers dat ze zowel door studentenoordelen als afgestudeerdenoordelen worden gedreven. Ervaringen na afstuderen kunnen altijd tot aanpassingen leiden, maar naar verwachting zal dit eerder gebeuren wanneer de oordelen van studenten al bij voorbaat hoger of lager waren dan redelijkerwijs had mogen worden verwacht. In de statistiek heet dit verschijnsel "regressie naar het gemiddelde": er is veel meer kans dat een hoge score naar beneden wordt bijgesteld dan naar boven, en ook meer kans dat een lage score naar boven wordt bijgesteld dan naar beneden. De verschuiving is dus voor een deel een correctie van onrealistisch hoge of lage gemiddelde oordelen van studenten, en heeft dus niet altijd per se een inhoudelijke betekenis.

Om een beter beeld te krijgen van de toegevoegde waarde van de HBO-Monitor ten opzichte van NSE, kunnen we de gemiddelde HBO-Monitor oordelen in twee componenten splitsen: (1) het deel dat door NSE-oordelen wordt voorspeld, en (2) het onverklaarde restant. ${ }^{3}$ Deze componenten tellen samen met de constante op tot het oorspronkelijk gemiddelde HBO-oordeel, en kunnen dan apart worden gebruikt in vervolganalyses. Van bijzonder belang is in hoeverre het onverklaarde restant significant samenhangt met kenmerken van afgestudeerden en hun ervaringen sinds afstuderen. Van belang hierbij is het feit dat dit restant geheel ongecorreleerd is met het NSE oordeel. Dit is dus precies het deel van het HBO-oordeel dat we niet al hadden kunnen weten op basis van het NSE-oordeel.

3 Deze componenten zijn gemakkelijk te verkrijgen door regressiemodellen op te stellen met als afhankelijke variabelen de gemiddelde $\mathrm{HBO}$-oordelen, en als verklarende variabelen de bijbehorende gemiddelde NSE-oordelen. De voorspelde waarde en het onverklaarde restant zijn dan als variabelen weg te schrijven. 
Voor dit hoofdstuk is een aantal additionele regressieanalyses gedraaid, met als afhankelijke variabelen deze twee componenten van de oordelen, en als voorspellers de kenmerken en ervaringen van afgestudeerden. Dit stelt ons in staat om na te gaan in hoeverre een eventuele samenhang tussen deze kenmerken en ervaringen en HBO-Monitor oordelen zich vooral beperkt tot het deel dat we al op basis van NSE hadden kunnen weten - het voorspelde deel - of ook terug te vinden is in het deel dat niet door NSE-oordelen kon worden voorspeld - het onverklaarde restant. We beginnen met het effect van het aandeel vrouwen in de opleiding.

FIGUUR 4.1 Effect van aandeel vrouwen onder afgestudeerden op componenten van HBO-Monitoroordelen

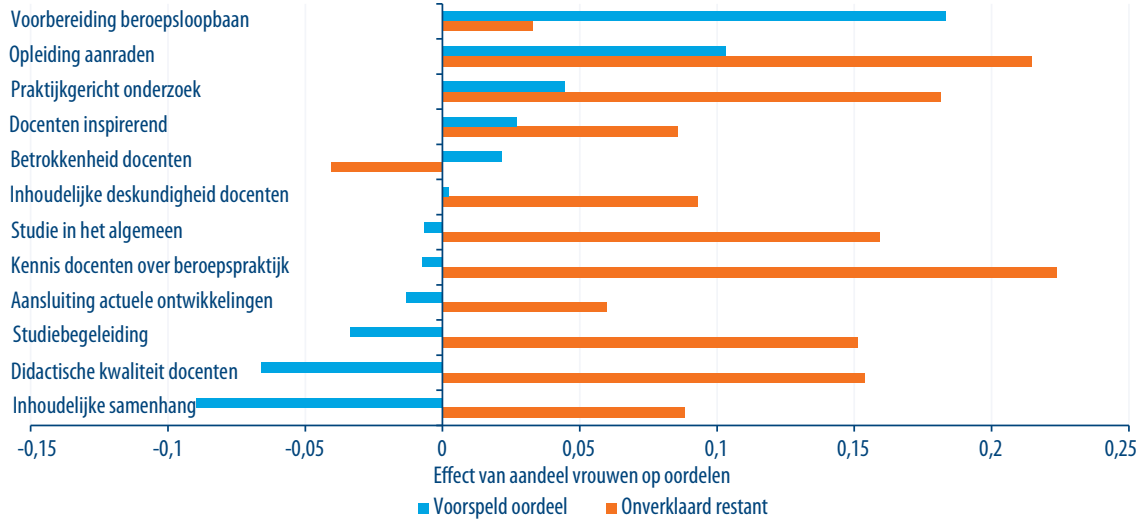

Uit figuur 4.1 blijkt dat het aandeel vrouwen van een opleiding positief samenhangt met een aantal oordelen van studenten - met name voorbereiding op de beroepsloopbaan en de bereidheid de opleiding aan te raden - en sterk negatief met het studentenoordeel over beoordelingscriteria. Veel interessanter is echter de bevinding dat het aandeel vrouwen van een opleiding positief samenhangt met het onverklaarde restant op de meeste oordelen. De sterkte van het verband varieert per aspect, en in een aantal gevallen is het effect zeer zwak of zelfs negatief, maar over de hele linie lijkt het specifiek deel van het oordeel van afgestudeerden dat niet door NSE-oordelen kon worden voorspeld, veel positiever te zijn bij opleidingen met veel vrouwen dan bij opleidingen met relatief meer mannen. Studenten van typische "vrouwenopleidingen" lijken dus veel meer geneigd om na afstuderen hun mening over de opleiding in positieve zin bij te stellen dan studenten van typische "mannenopleidingen".

Figuur 4.2 toont het effect van gemiddelde leeftijd op de twee oordeelscomponenten. Opleidingen waarin de gemiddelde leeftijd van afgestudeerden hoger ligt, worden over het algemeen al tijdens de studie door studenten negatiever beoordeeld. Er is echter nauwelijks een effect van gemiddelde leeftijd op het onverklaarde restant waarneembaar. 
FIGUUR 4.2 Effect van gemiddelde leeftijd van afgestudeerden op componenten van HBO-Monitoroordelen

Inhoudelijke deskundigheid docenten Kennis docenten over beroepspraktijk Betrokkenheid docenten Docenten inspirerend Didactische kwaliteit docenten Inhoudelijke samenhang Aansluiting actuele ontwikkelingen Voorbereiding beroepsloopbaan Praktijkgericht onderzoek Studie in het algemeen Studiebegeleiding Opleiding aanraden

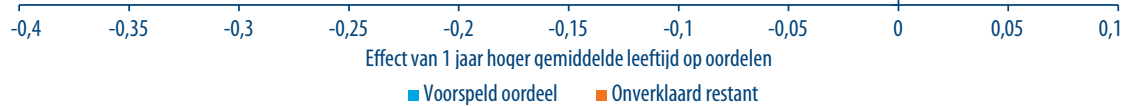

We zien een enigszins ander beeld wanneer we de relatie met aandeel niet-westerse migratieachtergrond bekijken (figuur 4.3). Hierbij zien we naast een effect op studentenoordelen ook in een aantal gevallen een negatieve relatie met het onverklaarde restante. Dit zien we met name bij oordelen over de docenten. Afgestudeerden van opleidingen met veel niet-westerse deelnemers zijn extra kritisch over docenten, bovenop het oordeel dat al eerder door studenten werd geveld.

FIGUUR 4.3 Effect van aandeel afgestudeerden met een niet-westerse achtergrond op componenten van HBO-Monitor-oordelen

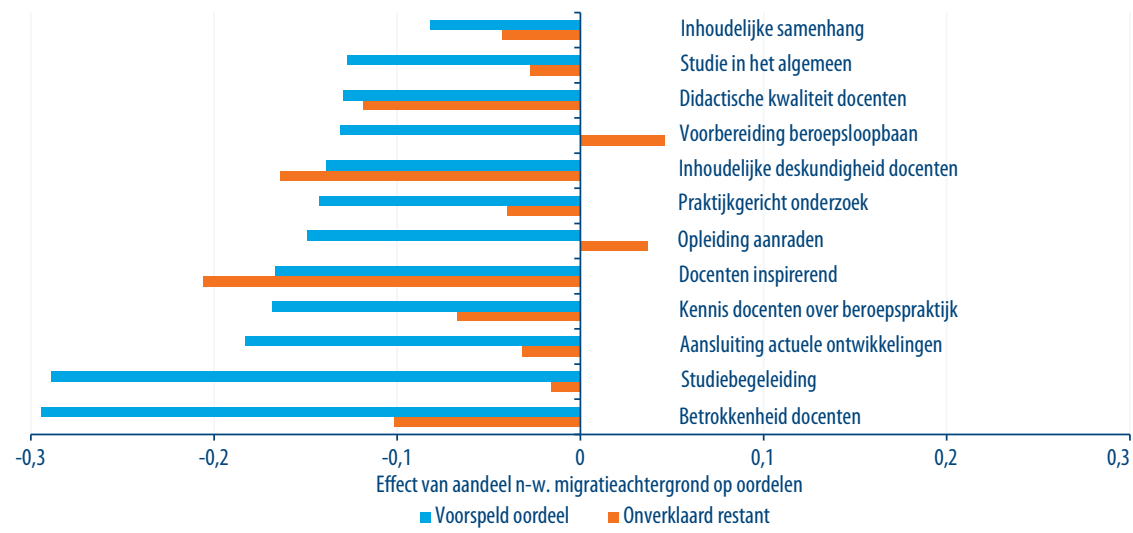

Figuur 4.4 toont voor een selectie oordelen het effect van aandeel instroom vanuit het vwo of MBO. De effecten op het onverklaarde restante weerspiegelen in de meeste gevallen de effecten van het deel dat al op basis van NSE oordelen kon worden voorspeld. Het effect op het onverklaarde restante is zelfs meestal sterker. De meeste effecten zijn positief, wat zou kunnen betekenen dat studenten en afgestudeerden van opleidingen 
met veel havo-instroom (de referentiecategorie) kritischer zijn over deze aspecten. De effecten van mbo-instroom zijn wel sterker in alle gevallen dan die van vwo-instroom. Bij oordelen die niet in figuur 4.4 zijn weergegeven zijn de effecten zeer zwak.

FIGUUR 4.4 Effect van aandeel doorstroom naar vervolgonderwijs op componenten van HBOMonitor-oordelen

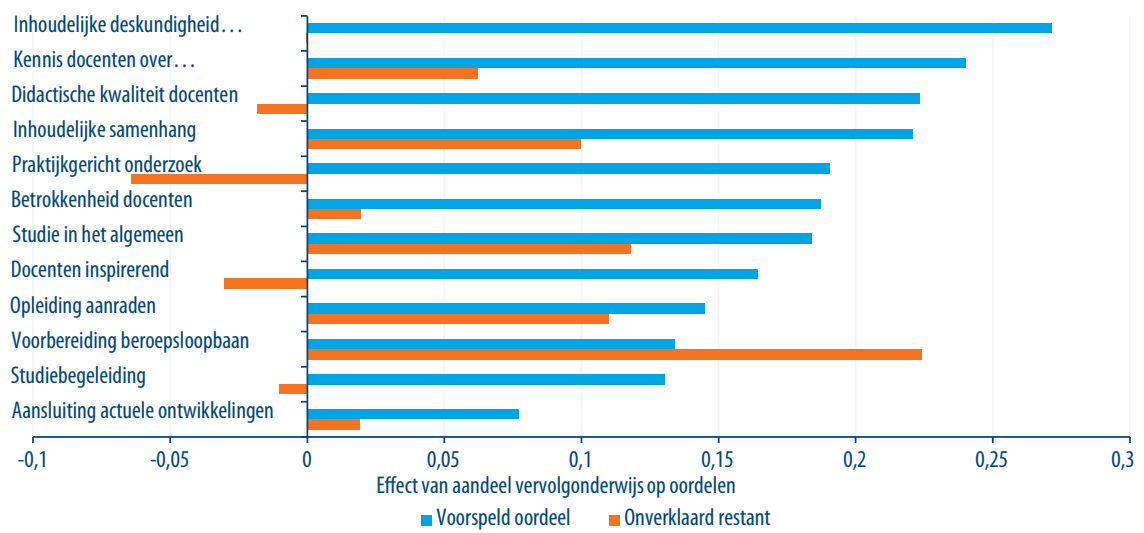

Figuur 4.5. ten slotte toont het effect van arbeidsmarktsucces op de twee oordeelscomponenten. Opvallend is dat de twee oordelen waarvan de voorspelde componenten het sterkst door de arbeidsmarkt wordt voorspeld - voorbereiding op beroepsloopbaan en de bereidheid de opleiding aan te raden - nog sterker met arbeidsmarktsucces samenhangen wanneer we naar het onverklaarde restant kijken. Ook in het geval van een tweetal andere oordelen - met betrekking tot de studie in het algemeen en de inhoudelijke samenhang - blijkt vooral het deel dat niet al door NSE-oordelen kon worden verklaard sterk samen te hangen met arbeidsmarktsucces. Het onverklaarde restant van deze vier aspecten wordt ook sterk beïnvloed door het aandeel afgestudeerden die na afstuderen doorstromen naar vervolgonderwijs. Dit lijken dus aspecten te zijn waarvoor de HBO-Monitor een sterke toegevoegde waarde heeft. 
FIGUUR 4.5 Effect van de gemiddelde arbeidsmarktindex van opleidingen op componenten van HBO-Monitor-oordelen

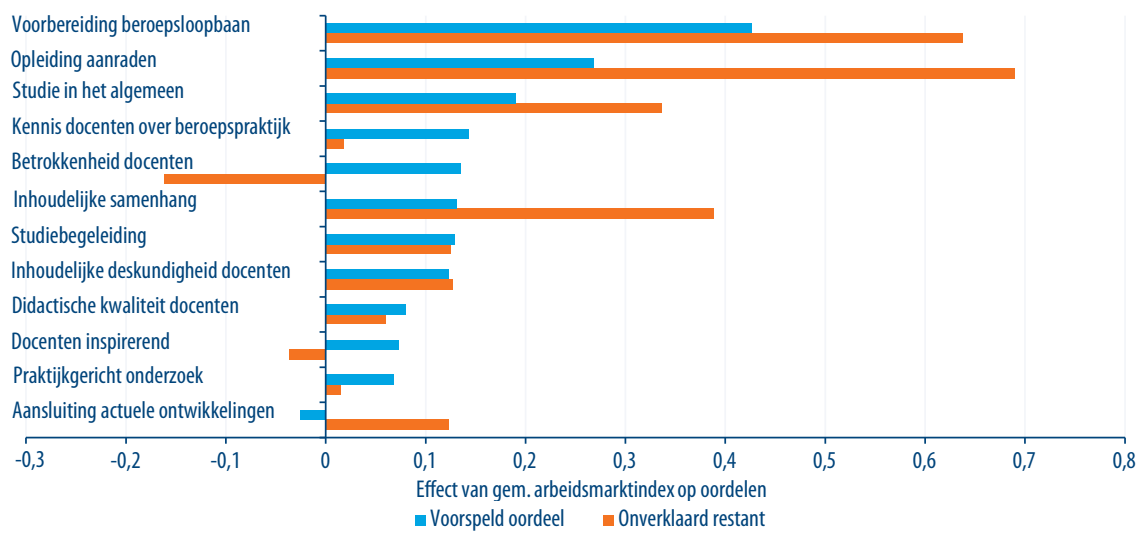





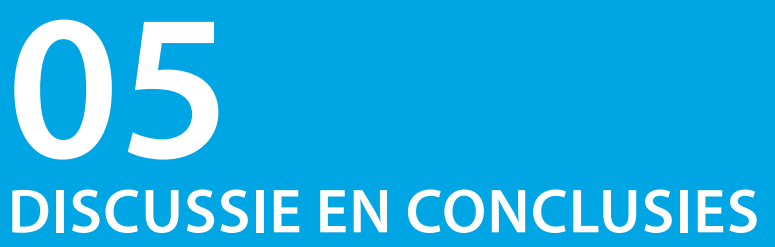

In dit rapport werdt aan de hand van een aantal analyses de zelf-gerapporteerde oordelen van studenten in het afstudeerjaar (in NSE) en afgestudeerden (HBO-Monitor) over verschillende aspecten van de opleiding tegen het licht gehouden. Het belangrijkste doel hierbij was om zicht te krijgen op de relatie tussen studenten- en afgestudeerdenoordelen, en zodoende licht te werpen op de vraag wat de toegevoegde waarde is van oordeelsvragen in de HBO-Monitor vragenlijst.

Er bleek een zeer sterke relatie te bestaan tussen HBO-Monitor oordelen en de NSE oordelen van studenten die in het laatste jaar van hun hbo-opleiding zitten. De correlaties zijn ook duidelijk terug te vinden op het niveau van opleidingen en instellingen. Deze sterke consistentie op basis van twee onderzoeken die volledig los van elkaar worden uitgevoerd, kan worden gezien als een krachtige validering van beide onderzoeken. De relatie is echter wel zwakker bij oordelen waarvoor een afwijkende antwoordschaal is gebruikt in de HBO-Monitor dan in NSE. Hieruit blijkt dat vergelijkingen gebaseerd op verschillende antwoordschalen relatief onbetrouwbaar kunnen zijn. De resultaten leken daarentegen niet gevoelig te zijn voor variaties in de vraagformulering van het betreffend aspect van de opleiding.

Voor zover als een vergelijking in de tijd mogelijk was, leken trends in NSE oordelen in grote lijnen consistent te zijn met trends in HBO-Monitor oordelen. Er dient hierbij echter opgemerkt te worden dat de overlap in uitstroomjaren tussen beide onderzoeken beperkt was. Het verdient dus aanbeveling om deze vergelijking over een aantal jaar te herhalen.

Op individueel niveau verschillen HBO-Monitor oordelen licht naar persoons- en achtergrondkenmerken van afgestudeerden zoals: geslacht, leeftijd, etniciteit en vooropleiding. De omvang van deze verschillen is echter klein, waardoor er geen reden is om te verwachten dat ze tot noemenswaardige bias leiden in de cijfers op geaggregeerd niveau van opleidingen en instellingen

Gemiddeld genomen is er sprake van weinig verschil tussen NSE en HBO-Monitor oordelen. Het enige verschil is dat afgestudeerden iets positiever dan studenten zijn 
over de meer persoonlijke kwaliteiten van hun docenten, en iets negatiever over de voorbereiding op de arbeidsmarkt. Wanneer we kijken naar oordelen van specifieke opleidingen binnen specifieke instellingen, is er echter vaak sprake van forse verschuivingen. In sommige gevallen zijn afgestudeerden dan positiever dan studenten, in andere gevallen juist negatiever.

In een aantal gevallen blijken de verschuivingen sterk samen te hangen met ervaringen die zijn opgedaan na het verlaten van de opleiding. Zo blijkt het gemiddelde arbeidsmarktsucces van specifieke opleidingen binnen specifieke instellingen positief samen te hangen met een verschuiving het oordeel over de voorbereiding op de arbeidsmarkt en de bereidheid om de opleiding aan anderen te raden. Het aandeel doorstroom naar vervolgonderwijs bleek vooral negatief samen te hangen met verschuivingen in oordelen met betrekking tot de docenten

Er zijn indicaties gevonden dat deze verschuivingen deels worden gedreven door individuele ervaringen op de arbeidsmarkt. Een veel sterker effect lijkt echter toe te schrijven aan de opleiding/instelling. Dit component van het effect lijkt tamelijk stabiel te zijn in de tijd.

Bij een viertal oordelen - voorbereiding op beroepsloopbaan, de bereidheid de opleiding bij familie en vrienden aan te raden, de studie in het algemeen en de inhoudelijke samenhang - blijkt dat het deel van de HBO-Monitor-oordelen dat niet reeds door NSE-oordelen kon worden verklaard, sterk samenhangt met ervaringen na het verlaten van de hbo-opleiding, in de vorm van arbeidsmarktsucces en doorstroom naar vervolgonderwijs. Dit lijken dus aspecten te zijn waarvoor de HBO-Monitor een bijzonder sterke toegevoegde waarde heeft. 


\section{BIJLAGE 1 ROBUUSTE SCHATTINGEN VAN GEMIDDELDE OORDELEN}

De in dit rapport gepresenteerde vergelijkingen zijn gebaseerd op gemiddelde oordelen van studenten en afgestudeerden per onderzoekseenheid. De onderzoekseenheden bestaan uit landelijk gedefinieerde opleidingen ( $\mathrm{CROHO}$-codes) per HBO-vestiging (BRIN + vestigingsnummer) voor uitstroomjaar 2015. Voor veel van de eenheden geldt dat we er per eenheid over weinig waarnemingen beschikken. Hierdoor kan worden aangenomen dat een ruwe gemiddelde in hoge mate aan meetfout onderhevig is. Om het storende effect hiervan te reduceren is gebruik gemaakt van multi-niveau analysemodellen. Multi-niveau modellen zijn hiërarchische modellen, waarbij individuele respondenten genest zijn in eenheden op hogere aggregatieniveaus (opleidingen en instellingen). Indien gewenst kunnen deze eenheden op hun beurt ook worden genest in eenheden op een nog hoger aggregatieniveau, die desnoods verder binnen nog grotere eenheden kunnen worden genest. Concreet wordt voor dit onderzoek studenten c.q. afgestudeerden genest binnen lokale hbo-vestigingen, die binnen hogescholen worden genest, die binnen landelijk gedefinieerde opleidingen worden genest. De variantie in de oorspronkelijke variabelen (in dit geval antwoorden op oordeelsvragen) wordt dan opgedeeld in een algeheel gemiddelde (niveau 1), een afwijking hiervan per CROHO-code (niveau 2), daarbinnen een afwijking per BRIN-code waarin de betreffende opleiding wordt aangeboden (niveau 3), en tenslotte voor ieder vestiging binnen de betreffende BRIN-code waarin de opleiding voorkomt (niveau 4). Er is binnen dit laatste niveau nog altijd de individuele afwijking per student/afgestudeerde. Deze informatie is echter niet te vergelijken tussen NSE en HBO-Monitor, en speelt derhalve geen verdere rol bij de analyses.

Op elk niveau wordt ervan uitgegaan dat de betrouwbaarheid van de geschatte waarde afhankelijk is van het aantal observaties waarop de schatting is gebaseerd. Zo is het algehele gemiddelde erg betrouwbaar, omdat het gebaseerd is op alle studenten c.q. afgestudeerden van het betreffende uitstroomcohort dat aan het onderzoek deelneemt. Op het niveau van landelijk gedefinieerde opleidingen dat daaronder valt, is het aantal observaties per eenheid beduidend lager, maar nog altijd in de meeste gevallen redelijk hoog. Bij sommige opleidingen is echter al sprake van een tamelijk klein aantal observaties. Hiermee wordt rekening gehouden bij het berekenen van de afwijkingen van het algehele gemiddelde. Eenvoudig uitgedrukt kunnen deze afwijkingen worden gezien als afwijking tussen het gewogen gemiddelde van de werkelijk gemiddelde afwijking en 
nul. Het gewicht wordt in dit geval gevormd door het aantal waarnemingen. Hierdoor wordt de geschatte afwijking bij grotere eenheden vooral bepaald door de werkelijk gemiddelde afwijking, terwijl bij kleinere eenheden deze afwijking in absolute zin naar beneden wordt bijgesteld. Hierdoor wordt voorkomen dat toevallige afwijkingen op basis van kleine aantallen even zwaar wegen als afwijkingen van dezelfde omvang op basis van grotere aantallen. Bij iedere verdere nesting neemt het aantal waarnemingen per eenheid verder af, maar verder blijft het principe hetzelfde.

Het grootste voordeel van deze methode is dus dat het ons in staat stelt om tamelijk betrouwbare schattingen te maken, zelfs in het geval van relatief kleine aantallen. De methode maakt gebruik van de constatering dan er een landelijke markt is waarop alle hogescholen die een bepaalde opleiding aanbieden zich begeven, en dat in het geval van kleine aantallen het aannemelijk is dat het werkelijke gemiddelde oordeel voor een hbo-vestiging die de betreffende opleiding aanbiedt dichter bij het landelijk gemiddelde van die opleiding ligt, dan bij het landelijk gemiddelde van het hbo als geheel. Er wordt dus informatie "geleend" van het gemiddelde van de betreffende opleiding om de schatting van het gemiddelde voor de betreffende vestiging betrouwbaarder te maken. 